IZA DP No. 9889

School Entry, Compulsory Schooling, and Human

Capital Accumulation: Evidence from Michigan

Steven W. Hemelt

Rachel B. Rosen

April 2016 


\title{
School Entry, Compulsory Schooling, and Human Capital Accumulation: Evidence from Michigan
}

\author{
Steven W. Hemelt \\ University of North Carolina at Chapel Hill \\ and IZA \\ Rachel B. Rosen \\ MDRC
}

Discussion Paper No. 9889

April 2016

IZA

P.O. Box 7240

53072 Bonn

Germany

Phone: +49-228-3894-0

Fax: +49-228-3894-180

E-mail: iza@iza.org

\begin{abstract}
Any opinions expressed here are those of the author(s) and not those of IZA. Research published in this series may include views on policy, but the institute itself takes no institutional policy positions. The IZA research network is committed to the IZA Guiding Principles of Research Integrity.

The Institute for the Study of Labor (IZA) in Bonn is a local and virtual international research center and a place of communication between science, politics and business. IZA is an independent nonprofit organization supported by Deutsche Post Foundation. The center is associated with the University of Bonn and offers a stimulating research environment through its international network, workshops and conferences, data service, project support, research visits and doctoral program. IZA engages in (i) original and internationally competitive research in all fields of labor economics, (ii) development of policy concepts, and (iii) dissemination of research results and concepts to the interested public.
\end{abstract}

IZA Discussion Papers often represent preliminary work and are circulated to encourage discussion. Citation of such a paper should account for its provisional character. A revised version may be available directly from the author. 


\section{ABSTRACT}

\section{School Entry, Compulsory Schooling, and Human Capital Accumulation: Evidence from Michigan*}

Extant research on school entry and compulsory schooling laws finds that these policies increase the high school graduation rate of relatively younger students, but weaken their academic performance in early grades. In this paper, we explore the evolution of postsecondary impacts of the interaction of school entry and compulsory schooling laws in Michigan. We employ a regression-discontinuity (RD) design using longitudinal administrative data to examine effects on high school performance, college enrollment, choice, and persistence. On average, we find that children eligible to start school at a relatively younger age are more likely to complete high school, but underperform while enrolled, compared to their counterparts eligible to start school at a relatively older age. In turn, these students are 2 percentage points more likely to first attend a two-year college, and enroll in fewer postsecondary semesters, relative to their older counterparts. We explore heterogeneity in these effects across subgroups of students defined by gender and poverty status. For example, we illustrate that the increase in the high school graduation rate of relatively younger students attributable to the combination of school entry and compulsory schooling laws is driven entirely by impacts on economically disadvantaged students.

JEL Classification: $\quad 120,121,128$

Keywords: school entry, compulsory schooling, postsecondary enrollment

Corresponding author:

Steven W. Hemelt

Department of Public Policy

University of North Carolina at Chapel Hill

Abernethy Hall, Campus Box 3435

Chapel Hill, NC 27599

USA

E-mail: hemelt@email.unc.edu

\footnotetext{
* The research reported here was supported by the Institute of Education Sciences, U.S. Department of Education, through Grants R305B110001 and R305E100008 to the University of Michigan. The opinions expressed are those of the authors and do not represent views of the Institute of Education Sciences (IES) or the U.S. Department of Education. This research used data structured and maintained by the Michigan Consortium for Educational Research (MCER). MCER data are modified for analysis purposes using rules governed by MCER and are not identical to data collected and maintained by the Michigan Department of Education (MDE) and/or Michigan's Center for Educational Performance and Information (CEPI). Results, information, and opinions solely represent the analysis, information, and opinions of the author(s) and are not endorsed by, nor do they reflect the views or positions of, grantors, MDE and CEPI or any employee thereof. We are grateful for helpful comments and suggestions from Susan Dynarski, Eric Eide, Brian Jacob, and numerous seminar participants at the University of Michigan and the Association for Education Finance and Policy (AEFP) 2014 meetings in San Antonio, TX.
} 


\section{Introduction}

Across the United States, two types of policies work in tandem to structure the amount of time a student is legally required to spend in public K-12 schooling. The first dictates the age at which children can start school. The second sets a minimum age at which students can drop out of school. Depending on a child's date of birth, this set of policies has different implications for the amount of time she is legally compelled to remain in school: For example, students who start school relatively young for grade reach the legal age of dropout after acquiring more formal time in school than their older peers. These two policies have spawned several lines of rich inquiry.

One line of research has focused on questions concerning the impacts of school starting age on academic outcomes such at test scores (Bedard \& Dhuey, 2006; Datar, 2006; Dobkin \& Ferreira, 2010; Elder \& Lubotsky, 2009). The consensus from this line of inquiry is that relatively older students perform better than their younger counterparts. Recent work based in the United States and abroad argues that this performance advantage is not driven by the ability of relatively older students to “learn better,” but rather by “age-at-test” effects (Black, Devereux, \& Salvanes, 2010) and the stock of skills accumulated prior to kindergarten entry (Elder \& Lubotsky, 2009).

A second line of research has exploited changes in the legal dropout age or the intersection of school starting age and compulsory schooling laws to examine net effects on long-run outcomes such as educational attainment and earnings (Angrist \& Krueger, 1991;

Bedard \& Dhuey, 2006). A consensus seems to be developing that there is little to no effect of this set of laws on labor market earnings (Black et al., 2010; Dobkin \& Ferreira, 2010; Fredriksson \& Ockert, 2014) yet, impacts on measures of longer-run educational attainment (especially among different subgroups of students) remain less clear. 
In this paper, we use rich student-level administrative data from the state of Michigan covering ten school years (2002-2003 through 2012-2013) to estimate the net impact of school starting age and compulsory schooling laws on educational attainment through high school, academic performance in high school, postsecondary enrollment, choice, and persistence. In addition, we examine whether impacts on educational progression and achievement during the K-8 years found in past work appear in the Michigan context. We employ a regressiondiscontinuity (RD) design, wherein we compare the educational experiences of students whose birth dates caused them to just barely miss the calendar cutoff for starting kindergarten in a given year to students who barely met this cutoff. The identifying assumption is that these two groups of students are similar in all ways except one, the age at which they are eligible to start public schooling. Therefore, any differences in later outcomes can be attributed to this set of laws and not to other personal, family, or school-level factors known to impact progression through school, performance, and educational attainment.

Several recent studies have explored the longer-run impacts of school entry and compulsory schooling laws on postsecondary and labor market outcomes (e.g., Hurwitz et al., 2015; Dobkin \& Ferreira, 2010). We add to this group of studies a few ways: First, we study the net effects of this set of laws within one state's policy context, wherein we can follow cohorts of students from elementary school through college. This allows us to clearly detail the evolution of any postsecondary effects we uncover (in terms of impacts of these laws on educational outcomes earlier in students' lives). Second, we explore how this set of laws differentially affects our postsecondary outcomes of interest by policy-relevant subgroups of students (e.g., by gender and economic disadvantage). Finally, we contribute to the collective external validity of these recent findings. In a literature where the policy settings (e.g., domestic versus international), 
samples (e.g., national versus state-specific; all students versus students with scores on a collegeentry test), and data quality (e.g., self-reported versus administrative outcomes) vary across studies, it is important to amass evidence from different policy contexts and datasets on the same underlying outcomes of interest.

To preview results, we find that students eligible to start kindergarten at a relatively younger age are about 1.5 percentage points more likely to graduate from high school, compared to their older counterparts. This effect is driven almost entirely by impacts on economically disadvantaged students (i.e., those eligible for free or reduced-price meals). Children eligible to start school relatively younger are as likely to attend college as their older counterparts, but enroll in different types of institutions. Specifically, these students are 2 percentage points more likely to first attend a two-year college. In addition, we find evidence that students eligible to start kindergarten at a relatively younger age enroll in fewer semesters of college, within three years of expected on-time high school graduation. We discuss heterogeneity in these postsecondary effects by students' gender and poverty status.

The paper unfolds as follows: The next section summarizes the most salient extant literature and situates our research within this body of work. Section III describes the Michigan policy context in detail. In sections IV and V, we describe our data and empirical approach. Section VI presents our main findings. Section VII concludes with a discussion of the policy implications of our results.

\section{Literature Review}

Angrist and Krueger (1991) were the first to recognize the natural experiment created by the intersection of season of birth, school starting age, and compulsory schooling laws. They concluded that about 25 percent of potential dropouts remained in school because of compulsory 
schooling laws. Since their seminal work, and adopting similar methodologies, many researchers have examined the impacts of school entry and compulsory schooling laws on educational, labor market, and socio-behavioral outcomes (Angrist \& Krueger, 1992; Bedard \& Dhuey, 2006; Black et al., 2011; Cook \& Kang, 2013; Dobkin \& Ferreira, 2010). ${ }^{1}$ On balance, the evidence suggests that students eligible to start school younger are more likely to graduate from high school and less likely to commit crime. ${ }^{2}$ Yet, despite these positive outcomes, there seems to be little to no effect on long-run labor market outcomes, such as wages and employment. For example, Dobkin and Ferreira (2010) use restricted-access Decennial Census Long Form data for a sample of the population in California and Texas and find no evidence that school entry laws and the additional attainment that results from such policies leads to differences in employment rates or wages. Their null findings hold across student subgroups defined by age, gender, and race. Evidence from the international context generally supports this finding. Fredriksson and Ockert (2014) follow children born between 1935 and 1955 in Sweden and conclude that age at the start of school has little effect on discounted lifetime earnings, but influences the allocation of labor supply over the life-cycle: Children who start school relatively older earn less early in their careers due to later entry into the labor market, but more around the time of retirement due to working longer. The effects may be specific to the Swedish context where there is virtually no grade retention, and all but a few children progress through school in the grade cohort to which they are assigned by date of birth.

\footnotetext{
${ }^{1}$ Much of this literature has (by necessity) relied on self-reported outcome measures from the Current Population Survey (CPS), and Census data, as well as nationally representative surveys such as the National Longitudinal Surveys of Youth (NLSY) and the National Educational Longitudinal Survey (NELS; Angrist \& Krueger, 1992; Dobkin \& Ferreira, 2010; Elder \& Lubotsky, 2009; Oreopoulos, 2007; Bedard \& Dhuey, 2006). Further, the data used in most of these analyses were representative of much earlier birth cohorts (i.e., mostly children born during the 1930s through the 1960s). We use data on much more recent birth cohorts (i.e., the 1990s) to explore how the impacts of school entry and compulsory schooling laws may have evolved over time.

${ }^{2}$ For girls, Black and colleagues (2011) find that starting school younger increases the likelihood of giving birth as a teenager.
} 
Other scholars have examined the shorter-run academic achievement effects of starting kindergarten as either the relatively oldest or youngest student in a grade cohort. These studies consistently found that students who start younger have weaker short-run academic performance than their older peers, in both domestic and international contexts (Bedard \& Dhuey, 2006). However, there is disagreement in the literature about how long this age-advantage lasts. For example, while Smith (2009) finds that older students consistently perform better on tests through grade ten, Elder and Lubotsky (2009) find that age-based differences in academic performance almost completely disappear by grade eight. We add to this line of inquiry by exploring the net impact of school entry and compulsory schooling laws in Michigan on students' performance on the ACT test in $11^{\text {th }}$ grade, which became mandatory for all Michigan students in 2007.

Regardless of the duration of any advantages, parental perception that being relatively old for grade is academically (and athletically) beneficial for students has led to increases in the number of students starting school a year later than when they were eligible (i.e., "red-shirting”). This practice has been utilized more frequently with white boys from more economically advantaged households, and least utilized by parents of Black and Hispanic children, who are also often less financially well-off and may not be able to afford an additional year of childcare outside the public school system (Deming \& Dynarski, 2008). Variation in such practices by gender, race, ethnicity, and income level underscores the need to better understand the impacts of school entry and compulsory schooling laws on longer-run outcomes for these subgroups of students. We leverage our large, detailed, state-level administrative dataset to examine the evolution of any subgroup effects within one policy context. 
The recent study by Hurwitz et al. (2015) is the most similar to our work. The authors examine postsecondary impacts of school entry and compulsory schooling laws across the United States, using the universe of SAT test-takers in the high school graduation cohorts of 2004 through 2008. They find that relatively younger students are more likely to first attend twoyear colleges, and are less likely to take (and pass) Advanced Placement (AP) exams during high school. We find similar results in Michigan in terms of outcomes that measure college choice, but there is a key difference between our work and that of Hurwitz et al. (2015) that creates implications for interpretation of findings. First, since the SAT is a voluntary test for college admission (in most states), Hurwitz et al. (2015) begin with a sample of students who are more advantaged and more likely to enroll in college than the full census of public school students in a single state. Since the $\mathrm{ACT}^{3}$ became mandatory for high school students in Michigan in 2007, we are able to explore impacts of school entry and compulsory schooling laws on achievement in high school as well as subsequent postsecondary enrollment and choice outcomes. This is particularly important because, if one of the net effects of school entry and compulsory schooling laws is to increase the share of (younger) students persisting to $11^{\text {th }}$ grade, we may expect effects on subsequent postsecondary outcomes to look different given that students induced to complete $11^{\text {th }}$ grade are now also being compelled to take a test used for college entry. As additional states integrate the ACT or SAT into their suite of mandatory high school tests, ${ }^{4}$ our results will reflect an increasingly common policy landscape.

\footnotetext{
${ }^{3}$ The ACT is a college admissions test that competes with the SAT. Fore more information about the ACT (SAT) please consult http://www.act.org/content/act/en/products-and-services/the-act.html (https://collegereadiness.collegeboard.org/sat).

${ }^{4}$ As of 2014, 11 states have adopted either the ACT or SAT as a mandatory test for high school students (Hyman, 2014).
} 


\section{Policy Context}

Until recently, Michigan had one of the latest school starting dates in the country: Students had to turn five by December 1 of the kindergarten year. Currently, all but eight states have school starting dates that occur earlier in the school year than December, with the earliest being July 31 (Nebraska, and Hawaii, as of the 2014-15 school year) and the latest being October 15 (Maine). Of the remaining eight, only Connecticut has a later statewide school entry date (January 1), while the others allow local education agencies (LEAs) to decide independently (e.g., New York). ${ }^{5}$ Accordingly, many more students in Michigan have been eligible to begin kindergarten at age four than elsewhere. The Michigan policy has meant that a child born on November 30 was still four when school began in September, while a child born just two days later on December 2 was a full year older, and closer to age six, when she began school the following year, providing a wide range of ages, and possible developmental differences within kindergarten cohorts.

Beginning in the 2013-2014 school year, the statewide school entry age began rolling back one month per year for three years, culminating in a school entry cutoff of turning age five by September $1^{\text {st }}$ (at the beginning of the 2015-2016 school year). This change means that every student now has to be at least five by the first day of school. Michigan is also in the process of changing its compulsory schooling laws. Beginning with the graduating class of 2016, students will not be allowed to drop out of high school until age 18; at least not without parental permission. In terms of future research, these policy shifts will provide another source of plausibly exogenous variation with which to study the effects of school entry age and compulsory schooling laws on a range of outcomes.

\footnotetext{
${ }^{5}$ Education Commission of the States: http://ecs.force.com/mbdata/mbquestRT?rep=Kq02
} 


\section{Data and Analytic Samples}

For all analyses, we use student-level administrative data collected by the Michigan Department of Education (MDE) and the Center for Educational Performance and Information (CEPI), provided through the Michigan Consortium for Education Research (MCER). These records contain detailed information on the characteristics and educational experiences of all students enrolled in public schools in Michigan, beginning in the 2002-2003 school year. Data include information on students' date of birth, city of birth, race, ethnicity, eligibility for free and reduced-price meals (FARM), and test scores. These data have also been matched to students’ college enrollment records obtained from the National Student Clearinghouse (NSC), allowing us to measure college-going for students through August of 2012. For each student who matches to the NSC's database (by name and birth date), a complete history of postsecondary enrollment experience is returned (Dynarski, Hemelt, \& Hyman, 2013). ${ }^{6}$

In our analyses we employ three samples of students: The first group is a set of birth cohorts that we can follow through at least three years of potential postsecondary experience. We refer to this group as the college sample. These students were born between June 4, 1989 and May 30, 1992. We then expand the number of birth cohorts in our analytic sample when we examine high school outcomes to those students born between June 4, 1989 and May 30, 1994. We refer to this group as our high school sample. Finally, to examine impacts on grade progression during elementary and middle school, we use students born between June 4, 1997 and May 30, 1999. We refer to this group as our K-8 sample. Our sample selection is driven by

\footnotetext{
${ }^{6}$ The earliest (on-time) high school graduates in our college sample could enter college is in the fall of 2007. Therefore, to ensure consistency in the operationalization of this key outcome across birth cohorts, we construct our college enrollment variable based solely on the stock of institutions that were reporting enrollment information to the NSC as of September 2007. In practice, this does not turn out to be a very binding restriction, as enrollment coverage in Michigan of the NSC data in 2007 is high overall (i.e., 84.4\% for all institutions, public and private), and especially high among public two-year and public four-year institutions (i.e., 92\% and 97\%, respectively). Coverage only rises (across all types of colleges) in later years. See Dynarski, Hemelt, and Hyman (2013) for a comprehensive discussion of coverage rates of NSC data.
} 
the desire to use data on the maximum number of students for each set of outcomes (college, high school, K-8). ${ }^{7}$ Across all three samples, we exclude special education students. ${ }^{8}$

Although an ideal panel would allow us to follow the same students from kindergarten through college, our data span just about a decade. However, because these samples of students were all born within 10 years of each other, and during a time period in which Michigan did not change its school entry policy nor its dropout policy, we assume that the experiences of the younger cohorts of students we observe in primary grades are similar to the experiences the older cohorts of students likely had in the primary grades, allowing us to reasonably use the findings from the K-8 cohort of students to inform our understanding of outcomes for the high school and college cohorts. In addition, we use the K-8 sample to explicitly test for differential rates of sample attrition. Finding no such evidence, we assuage concerns about beginning our high school and college analytic samples with students who we see somewhere in our Michigan data at ages 14 and 15 .

Our main analyses focus on students in the high school and college samples, whom we first observe in $8^{\text {th }}$ grade. We begin with $8^{\text {th }}$ graders because this is the youngest group we can follow into higher education. The oldest of these students were eligible to begin $8^{\text {th }}$ grade in 2002-2003, the first year for which we have data. The youngest students were eligible for $8^{\text {th }}$ grade in 2005-2006.

One limitation with these two samples is that, even though we know students' birth dates and can calculate when they should have enrolled in kindergarten, we do not actually observe kindergarten entry. Thus, if a student is not on-time, we do not know if she entered school on-

\footnotetext{
${ }^{7}$ Our high school results are robust to analyses that use only the college sample. Results are available upon request from the authors.

${ }^{8}$ Specifically, within each sample, we exclude students who are educated in a special education classroom full time (and are therefore "ungraded"). We do not drop students with special education flags who appear in regular classrooms (with regular grade-level information).
} 
time and was retained, or if she was red-shirted. We also do not know if she attended Michigan public schools prior to $8^{\text {th }}$ grade. To control for the possibility that students did not start school in Michigan, but moved to the state from other places with different school entry policies, possibly inducing different levels of attainment prior to when we observe them, we restrict these samples to students who were born in Michigan. Although these students could have moved out of and back into Michigan between birth and $8^{\text {th }}$ grade enrollment, this restriction reduces the likelihood that any results are driven by the mobility of students who enter the state later, and are likely different from those rooted in Michigan.

Table 1 presents descriptive statistics about the three analytic samples. Looking across these samples, it appears that Michigan did undergo some demographic changes between 1989 and 1999 (i.e., the range of birth years that encompasses our various cohorts). In particular, there was growth in the Hispanic population as a proportion of K-12 students, from approximately 2

percent to 6 percent, which in turn slightly shifted the overall race-ethnic composition of students across the state. In addition, the share of students eligible for free or reduced-price meals (FARM) is greater at the K-8 level (62 percent) than at the high school level (51 to 54 percent)

\section{Empirical Strategy}

We use a regression-discontinuity (RD) design to compare students on either side of the kindergarten enrollment cutoff, half of whom are eligible to start school a year prior to the other half. We construct the running variable such that the cutoff date of December 1 is equal to zero, and extend the variable 180 days in each direction. This means that the earlier birthdays are those between June 4 and December 1, and the later birthdays are those that fall between December 2 and May 30. Students whose birthdays fall in the four-day window between the tails of the running variable are dropped. We define treatment as being eligible to start kindergarten at a 
relatively younger age, and refer to the group of students with birthdays on or before the enrollment cutoff as the treatment group, and the group of students with birthdays after the enrollment cutoff as the control group.

We first examine graphical evidence of any discontinuities in our outcomes of interest around the birth date cutoff. We then progress to estimating parametric specifications of the following basic type:

$$
Y_{i c}=\alpha+\beta_{1} T_{i c}+f\left(R_{i c}\right)+\beta_{x} X_{i c}+\delta_{c}+\varepsilon_{i c}
$$

where $Y_{i c}$ is the outcome of interest (e.g., retained in K-8, graduate high school, enroll in college) for student $i$ in birth cohort $c . T_{i c}$ is a binary indicator equal to one if student $i$ in birth cohort $c$ was born on or before the cutoff date of December 1 , and $f\left(R_{i c}\right)$ represents a flexible function of the running variable: the distance between student i's birthday and the cutoff date (in days), centered at zero. For example, $R_{i c}$ is equal to zero for a student born on December 1,10 for a child born on December 11, and -12 for a student born on November 18. We control linearly for the running variable, but interact it with the treatment indicator to allow the relationship between date of birth and the outcome to vary on either side of the cutoff. $X_{i c}$ is a vector of observable characteristics likely associated with the outcomes of interest, and includes information on students' gender, race and ethnicity, eligibility for free or reduced-price meals (FARM), and limited English proficiency status (LEP). Finally, $\delta_{c}$ is a vector of birth-cohort dummies and $\varepsilon_{i c}$ is a stochastic error term. Within this parametric setup, $\beta_{1}$ gives the intent-to-treat (ITT) estimate of being eligible to start school a year earlier than the control group. 
We then estimate the parametric models specified above as well their nonparametric analogues ${ }^{9}$. We see very similar results across parametric and nonparametric analyses, likely due to the quite linear relationship between our running variable and outcomes in the neighborhood of the discontinuity (Angrist \& Pischke, 2009). Therefore, we focus on our parametric results in the discussion that follows. For our parametric approach, we present results from several windows of data, zeroing in on the smallest window for which we have adequate power to detect effects (i.e., within 30 days of the cutoff). This allows the reader to see and judge tradeoffs between precision and potential bias across a range of estimates. Other work in this area has used date ranges between 50 and 70 days, on either side of the birth date cutoff (Cook \& Kang, 2013; McCrary \& Royer, 2006). Our relatively large sample sizes allow us to use ranges of 30 and 45 days. We consider average impacts and explore potential heterogeneity in effects by student gender and eligibility for free or reduced-price meals (FARM).

\section{Results}

Although our primary interest lies in the high school and postsecondary outcomes, we begin by graphically examining a few particular outcomes based on the K-8 sample. We do so for two reasons: First, we can observe kindergarten entry and more clearly depict the identifying variation we use across all samples. Second, we test assumptions about sample attrition through grade 8 (i.e., when our high school and college samples begin).

In Figure 1 we explore compliance. In Panel A, we graph the relationship between the running variable and age in years at school entry. The parametric estimate of the discontinuity is 0.79 years. If compliance were perfect, the gap would be a full year. It is this variation in age at kindergarten entry that later intersects with compulsory schooling laws and would compel an on-

\footnotetext{
${ }^{9}$ Our nonparametric analyses employ a series of local linear regressions of degree zero with a bandwidth of 30 days and a triangular kernel.
} 
time student to remain in school longer than her older counterparts. In Panel B, we graph the relationship between a student's first appearance in kindergarten and her predicted year of kindergarten entry based on her date of birth. Though the overall redshirting rate (for the entire analytic sample) was 4.4 percent, students born right to the left of the cutoff are substantially more likely to be redshirted (by about 18 percentage points). Our overall estimate of redshirting is in line with national estimates from Bassok and Reardon (2013), who estimate a national redshirting rate of between 4 and 5.5 percent. In Panel B, as we move leftward along the x-axis away from the cutoff, the relative age difference shrinks and the likelihood of redshirting declines. $^{10}$

The validity of the RD approach rests on the assumption that there is smoothness in the running variable through the cutoff determining treatment. We test for heaping of births to one side or the other of the school entry cutoff date using the approach outlined by McCrary (2008) and find no such evidence of birth-date manipulation. ${ }^{11}$ In Figure 2, we calculate the share of students that leave our K-8 sample (regardless of whether they later return to the Michigan data). ${ }^{12}$ If families of younger students were moving out of Michigan at differential rates, we might be worried about our choice to begin the high school and college samples with students we observe around age 14 in our data. But, we find no evidence of differential sample attrition for students eligible to begin school at a younger age.

\footnotetext{
${ }^{10}$ We conducted a simple descriptive, exploratory analysis of the demographic characteristics of students within ten days of the school entry cutoff in Figure 2 (i.e., from -10 to 0). We compared average characteristics of the subset of students within that window who delayed kindergarten entry to the characteristics of the subset who started on time. Resultant descriptives confirm patterns uncovered by Bassok and Reardon (2013): Of those who were redshirted, 40 percent were female, 89 percent were white, 5 percent were black, and 40 percent were eligible for free or reducedprice meals. Among those who started on time, 51 percent were female, 64 percent were white, 25 percent were black, and nearly 70 percent were eligible for free or reduced-price meals. Thus, in Michigan, redshirting is a phenomenon more common among male, white, and economically advantaged students.

${ }^{11}$ Specifically, we use the "DCdensity" command in Stata developed by McCrary (2008), and find no statistically significant difference in the density of births at the cutoff.

${ }^{12}$ The parametric RD estimate of the discontinuity within a window that spans 30 days on each side of the cutoff is very small and statistically insignificant: 0.009(0.008).
} 


\section{A. Effects on High School Outcomes}

We now examine effects of school entry eligibility on our high school attainment outcomes. Figure 3 presents the graphical depiction of these results while Table 2 reports the corresponding parametric estimates. On average, we find that students eligible to begin school a year younger are 1.6 percentage points more likely to enroll in $11^{\text {th }}$ grade, about 1 percentage point more likely to enroll in $12^{\text {th }}$ grade, and 1.5 percentage points more likely to graduate from high school than their older counterparts. ${ }^{13}$ Our effects are slightly larger than those of Dobkin and Ferreira (2010): In Texas and California, they find effects on high school graduation of 0.8 and 0.9 percentage points, respectively (p. 43). Yet, our results are much closer to those of Dobkin and Ferreira (2010) than to Cook and Kang's (2013) finding of a 4 percentage point difference in rates of completing $12^{\text {th }}$ grade in North Carolina (p. 26).

In addition to attainment, we can explore impacts of this set of laws on academic performance in high school. All but one of our birth cohorts were required to take the ACT test in their penultimate year of high school. Table 3 presents results where the outcome is composite ACT score, and confirm that students eligible to begin school a year younger score about 0.4 points (i.e., 0.08 standard deviations) lower on the ACT composite (relative to their older counterparts). ${ }^{14}$ These achievement results align with Smith (2009) and suggest that the underperformance of relatively younger students does persist beyond middle school into high school. ${ }^{15}$

\footnotetext{
${ }^{13}$ When we nonparametrically estimate the impacts on these same outcomes, we obtain nearly identical point estimates - all of which are statistically significant at the 10 percent level or lower.

${ }^{14}$ We obtain nearly identical results if we exclude the birth cohort of students for whom the ACT was not mandatory at the time they were in $11^{\text {th }}$ grade (i.e., those born in 1989-1990) from our sample.

${ }^{15}$ Specifically, these achievement effects are at the lower end of the range of effects on $10^{\text {th }}$ grade performance found by Smith (2009): By grade 10, he finds that older students' academic performance advantage is about $0.10 \sigma$ in numeracy, $0.11 \sigma$ in reading, and $0.19 \sigma$ in writing (p. 13).
} 


\section{B. Effects on College Outcomes}

We next turn to effects of this same set of laws on measures of postsecondary enrollment, choice, and persistence. Table 4 presents results for this set of outcomes. Figure 5 presents the corresponding graphs. We see evidence of a small positive (but statistically insignificant) effect on overall college-going of less than 1 percentage point. Any small effect on overall college attendance is driven by statistically significant increases in the likelihood that students first attend a two-year (rather than four-year) college. Impacts on outcomes that measure whether a student initially enrolls in a two-year or four-year college suggest that school entry and compulsory schooling laws affect college choice (i.e., the intensive rather than extensive margin of college-going). Specifically, students eligible to start school at a younger age are about 2 percentage points more likely to first attend a two-year college and 1.1 percentage points less likely to first attend a four-year college. ${ }^{16}$

We also examine the impact of these laws on the total number of college semesters in which a student enrolls during the three years after her expected, on-time high school graduation. We estimate that students eligible to begin school at a relatively younger age enroll in about 0.4 fewer semesters of college (of either part- or full-time intensity) than their older counterparts. This is an unconditional estimate (that is, those who did not attend college receive a value of zero semesters).

We conclude that students eligible to start school at a relatively younger age are no more likely to attend (any) college than their older counterparts. Rather, we find evidence that school entry and compulsory schooling laws shape the college choices of these students. Specifically,

\footnotetext{
${ }^{16}$ In addition, these students are no more likely than their older counterparts to ever attend a four-year. So, the impact on the outcomes measuring whether a student first attends a two-year college is not simply a proxy for later enrollment in a four-year college. Results for the "ever four-year college" outcome are omitted for parsimony and available from authors upon request.
} 
we find that this set of laws shifts the choices of relatively younger college-going students toward two-year rather than four-year colleges (relative to their older college-going peers). This finding is in line with Hurwitz et al. (2015) and underscores the need to consider how these policies shape the college-going trajectories of younger students, especially given recent evidence on the degree to which the selectivity of a college a student attends shapes her future welfare (e.g., Hoekstra, 2009; Cohodes \& Goodman, 2014).

We also find this set of laws to foster lower levels of postsecondary persistence among relatively younger students. Perhaps the relative underperformance of younger students in high school accounts for some of these postsecondary effects. That is, such students are induced to remain in high school longer, underperform on (mandatory) college entrance exams, and enter relatively weaker (i.e., two-year) postsecondary institutions. At least, this is one analytic story that is consistent with the joint results across our high school and college outcomes and with the Michigan policy context (i.e., the relatively recent adoption of a mandatory, free college entrance exam in $11^{\text {th }}$ grade). In contrast to the relatively advantaged sample of SAT test-takers studied by Hurwitz et al. (2015), these postsecondary persistence effects may be more representative of the impacts of such laws on the broad swath of public school students in a given state.

As a test of the validity of our RD design, we use our student-level covariates (i.e., female, white, black, Hispanic, FARM, LEP) as outcomes and present graphical evidence in Figure 5 on the smoothness of these covariates through the cutoff of interest. In no case do we estimate a statistically significant discontinuity in any of these student-level covariates at the cutoff. In addition, we see this same pattern of null results for our other samples (i.e., the high school and K-8 samples). 


\section{Heterogeneity in Impacts by Gender and Economic Advantage}

Given past evidence on the differences in impacts of school entry and compulsory schooling laws by gender and socio-economic advantage, we next explore heterogeneous effects on our high school and college outcomes by gender and eligibility for free or reduced-price meals (FARM). Table 5 presents these results.

The results in Table 5 are quite rich and provide considerable nuance to our basic high school and postsecondary findings. We find that relatively younger students across these four subgroups underperform on the ACT relative to their older counterparts - but the magnitude of that underperformance is greater for boys and FARM students. At the same time, while we see similar positive impacts on high school graduation for boys and girls of the offer to enter school a year earlier than their slightly older same-gender counterparts, we see substantial differences in the effect of this offer by FARM eligibility. Specifically, this set of laws induces about 3 percent more FARM students who are relatively young for grade to graduate from high school, compared to older FARM students (whereas the impact among non-FARM students is essentially zero). We therefore conclude that the overall positive impacts on educational attainment through the end of high school are being almost entirely driven by impacts on socio-economically disadvantaged students (of both genders).

When we look to heterogeneous effects of school entry and compulsory schooling laws along the college-going margin, we see that such laws appear to increase college-going among female and non-FARM students, by 2.7 and 3.1 percentage points respectively - and that these increases are primarily absorbed by increases within the two-year sector. In contrast, we see little impact of these laws on the overall college enrollment rates of male and FARM students, but clearer impacts on the college choices of such students. Specifically, males and FARM students 
are 2.5 and 1.2 percentage points less likely to first attend a four-year college (relative to a twoyear college). These heterogeneous effects illustrate which groups of students account for the mix of college (attendance and choice) effects we saw across the full sample. Taken together, these findings highlight important differences in the impacts of school entry and compulsory schooling laws on the educational performance and postsecondary pathways of students of different types.

\section{Effects on Progression through Elementary and Middle School}

Thus far, our analysis provides important information about the net, long-range impacts of school starting age and compulsory schooling laws. Yet, our high school and college analytic samples begin with students we can observe in $8^{\text {th }}$ grade. We know from prior literature that school starting age laws also impact performance and progression in elementary and middle school. These impacts necessarily shape later outcomes as students age into the time period where compulsory schooling laws begin to bind. To better understand this phenomenon, we examine grade progression patterns for students in our K-8 sample who attended school in the same policy context, just a few years later.

Figure 2 confirmed that leaving the Michigan K-8 data is unrelated to the treatment (i.e., the offer to start school a year earlier than one's peers). Therefore, we drop students who leave our data from the K-8 analytic sample for this grade progression analysis. Figure 6 examines the relationship between grade repetition and the age at which children are eligible to start school. We see a large discontinuity in the likelihood of ever repeating a grade during the K-8 years at the cutoff. Specifically, students eligible to start school at a relatively younger age are about 30 percentage points more likely to repeat a grade at some point during elementary or middle school. 
To explore the evolution of this overall impact, we estimate our RD model using the sample that includes students born within 30 days of either side of the school entry cutoff date on outcomes that measure whether a student is on-time in each grade (K-8). Figure 7 presents these grade-specific estimates. We base the construction of these on-time outcomes on fist-time appearance of students in grades. Therefore, the kindergarten bar can be interpreted as the difference in likelihood of delayed kindergarten entry (i.e., redshirting) for those just to the left of the cutoff compared to those just to the right. That is, students just barely eligible to start kindergarten at a relatively younger age are about 18 percentage points more likely to delay kindergarten entry.

Subsequent bars combine grade retention, grade skipping, and delayed entry into kindergarten (which puts a student off-track for all subsequent, observed outcomes). As we look across these bars an interesting pattern emerges- wherein the vast majority of the "ever repeat" effect is driven by an increased likelihood of repeating kindergarten or first grade. Specifically, students eligible to start school at a relatively younger age are about 43 percentage point less likely to enter first grade on time. This effect rises to 47 percentage points by second grade, but shows little movement between third and eighth grade. ${ }^{17}$ Thus, this pattern suggests that the majority of the "grade retention effect" occurs between kindergarten and grade 2. These results also underscore the fact that effects on our high school and college outcomes are net of the high rate of K-8 grade repetition among our “treatment” (i.e., relatively younger) students in Michigan.

\footnotetext{
${ }^{17}$ Cook and Kang's (2013) finding that a relatively younger student is 6 percentage points more likely to repeat a grade between the ages of 11 an 15 (p. 18) is quite in line with our finding that the largest impacts on grade retention occur in early elementary school grades (i.e., kindergarten through $3^{\text {rd }}$ grade), with small marginal increases to this likelihood in upper elementary school years and beyond. The magnitude of our early grade repetition findings is much larger than estimates from international contexts: For example, using data from Chile, McEwan and Shapiro (2008) find that a one-year delay in starting primary school decreases the probability of repeating first grade by 2 percentage points.
} 
We can use our estimate of the increased likelihood of redshirting at the cutoff to approximate the local average treatment effect (LATE) on our later outcomes of interest. The LATE provides a better sense of the effects on children who comply with the school entry law. We do so in the spirit of a two-sample instrumental variables (TSIV) setup (Angrist \& Pischke, 2009). First, we assume that the effect we calculate in our K-8 sample would be roughly similar in our high school and college samples. Second, we use this estimate to scale up the intent-totreat (ITT) effects of the offer to start kindergarten at a relatively younger age. For example, if we focus on one of our postsecondary outcomes that measure college choice, whether a student first enrolls in a two-year college, we estimate that the effect on compliers is 2.2 percentage points (i.e., 0.018/0.82). This approximated LATE is in the same ballpark as our estimate of the ITT effect on the same outcome: 1.8 percentage points.

\section{Conclusions and Policy Implications}

In this paper, we exploit the discontinuity in expected legal exposure to K-12 schooling created by school entry date and students’ exact birth dates to investigate the joint impact of school entry and compulsory schooling laws on a variety of educational outcomes along the K20 pipeline. Using rich administrative data on the universe of public school students in Michigan over a ten year period, we investigate the effects of being offered kindergarten entry eligibility a year earlier on high school performance, attainment, and college enrollment, choice, and persistence. To contextualize these findings, we also explore on-time grade progression from kindergarten through the $8^{\text {th }}$ grade for one sample of students. Overall, our results provide more nuanced answers to policy questions about school starting age and compulsory schooling laws in several ways. 
Similar to previous studies in this literature (e.g., Hurwitz et al., 2015; Cook \& Kang, 2013; Dobkin \& Ferreira, 2010; Bedard \& Dhuey, 2006), we find that students eligible to start school a year earlier (i.e., at a relatively younger age) persist at greater rates into grades 11 and 12, and complete high school at higher rates; yet, these same students demonstrate lower academic performance while in high school.

Along the postsecondary margin, we find no average effect of these laws on college enrollment (i.e., the point estimate is positive, small, and statistically insignificant). Yet, for females and economically advantaged students of both genders who are eligible to start school at a relatively younger age, we see impacts (of around 3percentage points) on college enrollment. Yet, the increases in the college-going rates for these subgroups take place entirely within the two-year college sector. For males and economically disadvantaged students eligible to enroll in kindergarten at a younger age, this set of laws seems to discourage initial matriculation in a fouryear postsecondary institution, and perhaps dampen the propensity to attend (any) college at all (i.e., coefficients for these subgroups are negative, small, and statistically significant when the outcome measures college enrollment along the extensive margin).

We also find that this set of laws fosters lower levels of postsecondary persistence among students eligible to start school at a relatively younger age. This finding is consistent with increased enrollment in two-year colleges, where degree and certificate programs are shorter and student attachment may be weaker than at four-year colleges. While speculative, it is plausible that the relative underperformance of younger students in high school accounts for some of these postsecondary effects. Similar to Dobkin \& Ferreira (2010), who argue that the net impact of lower academic performance and higher attainment explains null effects on adult earnings (p. 13), 
we argue that an additional net impact of these laws is a shift toward (and increased reliance on) potentially lower-quality postsecondary institutions and lower overall postsecondary persistence.

Yet, the boost in the high school graduation rate of students eligible to start school at a relatively younger age generated by these laws is a net positive. The fact that this increase is concentrated among low-income, traditionally disadvantaged students suggests that compulsory schooling policies are a potentially manipulable policy lever that can be expected to affect students most at-risk for dropout. Moreover, the fact that some subgroups of relatively younger students are enrolling in college at higher rates than their older counterparts (e.g., females) suggests that inducing some students to remain in high school longer may also propel them to acquire some postsecondary education (that they may have forgone had they been able to drop out of school sooner). This may be especially true in states like Michigan where all $11^{\text {th }}$ graders are required to take a college entrance exam. At the same time, the increase in high school graduation rates among FARM students who are relatively young for grade does not translate into higher college enrollment rates for this same group. Thus, policies designed to increase high school graduation among disadvantaged youth may need to be coupled with additional programs and supports if college access and enrollment are to be expanded for this same population of students.

Overall, our results present a mixed picture. The differential effects of the combination of school entry and dropout policies on different subgroups of students suggest that an appropriate policy response is unlikely to come in the form of shifting school entry policies - after all, under most feasible school entry schemes, some students will always be relatively younger and others relatively older. Rather, the interesting take-away from these findings is that the inducement to obtain more schooling produced by this combination of policies generates a positive impact for 
disadvantaged students in terms of secondary attainment, suggesting that policies aimed at increasing exposure to schooling for disadvantaged students may increase graduation among this vulnerable population. At the same time, our findings also illustrate that this set of laws increases high school graduation rates and college-going rates (within the two-year sector) for girls, but not for boys or economically disadvantaged students. Therefore, subsequent policy efforts to smooth and improve transitions from high school to postsecondary education might fruitfully target boys and low-income students. 


\section{References}

Angrist, J. D., \& Krueger, A. B. (1991). Does Compulsory School Attendance Affect Schooling and Earnings? The Quarterly Journal of Economics, 106(4), 979-1014.

Angrist, J. D., \& Krueger, A. B. (1992). The Effect of Age at School Entry on Educational Attainment: An Application of Instrumental Variables with Moments from Two Samples. Journal of the American Statistical Association, 87(418), 328-336.

Bassok, D., \& Reardon, S. F. (2013). “Academic Redshirting” in Kindergarten: Prevalence, Patterns, and Implications. Educational Evaluation and Policy Analysis, 35(3), 283-297.

Bedard, K., \& Dhuey, E. (2006). The persistence of early childhood maturity: International evidence of long-run age effects. Quarterly Journal of Economics, 121(4), 1437-1472.

Black, S. E., Devereux, P. J., \& Salvanes, K. G. (2011). Too Young to Leave the Nest? The Effects of School Starting Age. Review of Economics and Statistics, 93(2), 455-467.

Cohodes, S., \& Goodman, J. (2014). Merit aid, college quality and college completion: Massachusetts' Adams scholarship as an in-kind subsidy. American Economic Journal: Applied Economics, 6(4), 251-285.

Cook, P. J., \& Kang, S. (2013). Birthdays, Schooling, and Crime: New Evidence on the DropoutCrime Nexus (Working Paper No. 18791). National Bureau of Economic Research. Retrieved from http://www.nber.org/papers/w18791

Datar, A. (2006). Does Delaying Kindergarten Entrance Give Children a Head Start? Economics of Education Review, 25(1), 43-62.

Deming, D., \& Dynarski, S. M. (2008). The Lengthening of Childhood. Journal of Economic Perspectives, 22(3), 71-92.

Dobkin, C., \& Ferreira, F. (2010). Do school entry laws affect educational attainment and labor market outcomes? Economics of Education Review, 29(1), 40-54.

Dynarski, S. M., Hemelt, S. W., \& Hyman, J. M. (2013). The Missing Manual: Using National Student Clearinghouse Data to Track Postsecondary Outcomes (Working Paper No. 19552). National Bureau of Economic Research. Retrieved from http://www.nber.org/papers/w19552

Elder, T. E., \& Lubotsky, D. H. (2009). Kindergarten Entrance Age and Children’s Achievement: Impacts of State Policies, Family Background, and Peers. Journal of Human Resources, 44(3), 641-683.

Fredriksson, P., \& Ockert, B. (2014). Life-cycle effects of Age at School Start. The Economic Journal, 124(579), 977-1004. 
Hoekstra, M. (2009). The effect of attending the flagship state university on earnings: A discontinuity-based approach. Review of Economics and Statistics, 91, 171-724.

Hurwitz, M., Smith, J., \& Howell, J. S. (2015). Student age and the collegiate pathway. Journal of Policy Analysis and Management, 34(1), 59-84.

McCrary, J. (2008). Manipulation of the running variable in the regression discontinuity design: A density test. Journal of Econometrics, 142(2), 698-714.

McCrary, J., \& Royer, H. (2006). The Effect of Female Education on Fertility and Infant Health: Evidence from School Entry Policies Using Exact Date of Birth (Working Paper No. 12329). National Bureau of Economic Research. Retrieved from http://www.nber.org/papers/w12329

McEwan, P. J., \& Shapiro, J. S. (2008). The Benefits of Delayed Primary School Enrollment: Discontinuity Estimates Using Exact Birth Dates. Journal of Human Resources, 43(1), 129

Nichols, A. (2012). RD: Stata module for regression discontinuity estimation. Boston College Department of Economics. Retrieved from http://ideas.repec.org/c/boc/bocode/s456888.html

Oreopoulos, P. (2013). Should We Raise the Minimum School Leaving Age to Help Disadvantaged Youth? Evidence from Recent Changes to Compulsory Schooling in the United States. In J. Gruber (Ed.), An Economic Framework for Understanding and Assisting Disadvantaged Youth.

Smith, J. (2009). Can Regression Discontinuity Help Answer an Age-Old Question in Education? The Effect of Age on Elementary and Secondary School Achievement. The B.E. Journal of Economic Analysis \& Policy, 9(1), Article 48. 
Figure 1. Kindergarten Entry

\section{A. Age at Kindergarten Entry}

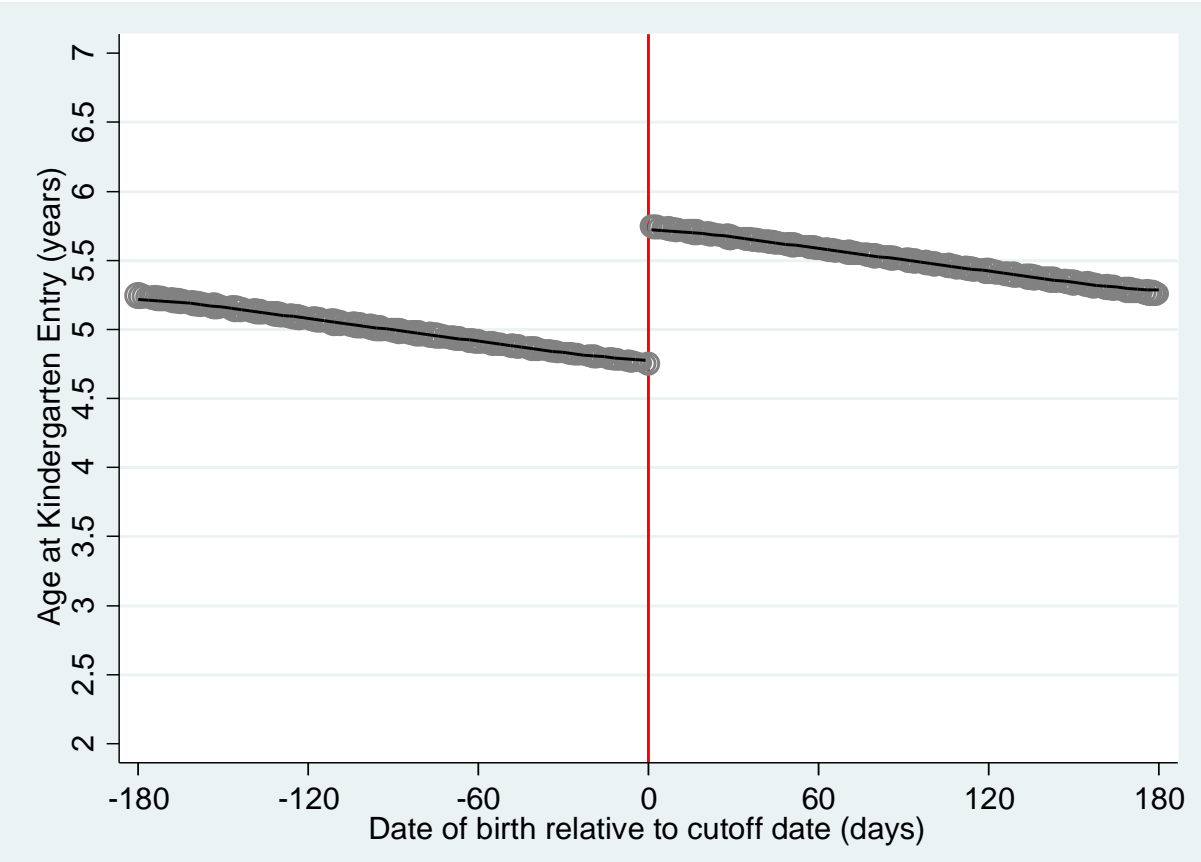

\section{B. Share of On-Time Kindergarten Entrants}

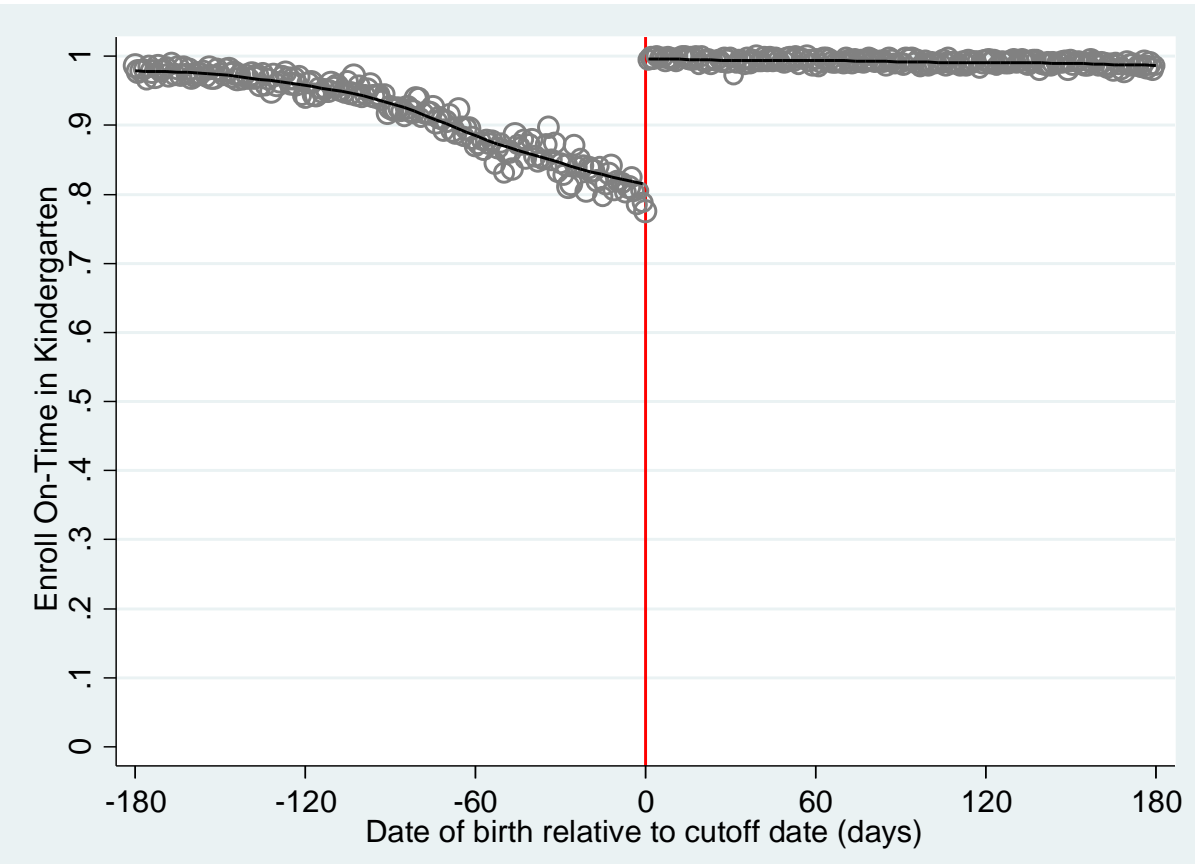

Notes: N = 227,417 students; Analytic (K-8) sample excludes special education students. Means are plotted for each day of birth and depicted as hallow circles; the larger the circle, the greater the number of students born on that day. A weighted local polynomial regression of degree zero fits a line on each side of the cutoff using a triangular kernel and a bandwidth of 30 days, where weights are equal to the number of students in each circle. 
Figure 2. Sample Attrition: K-8 Sample

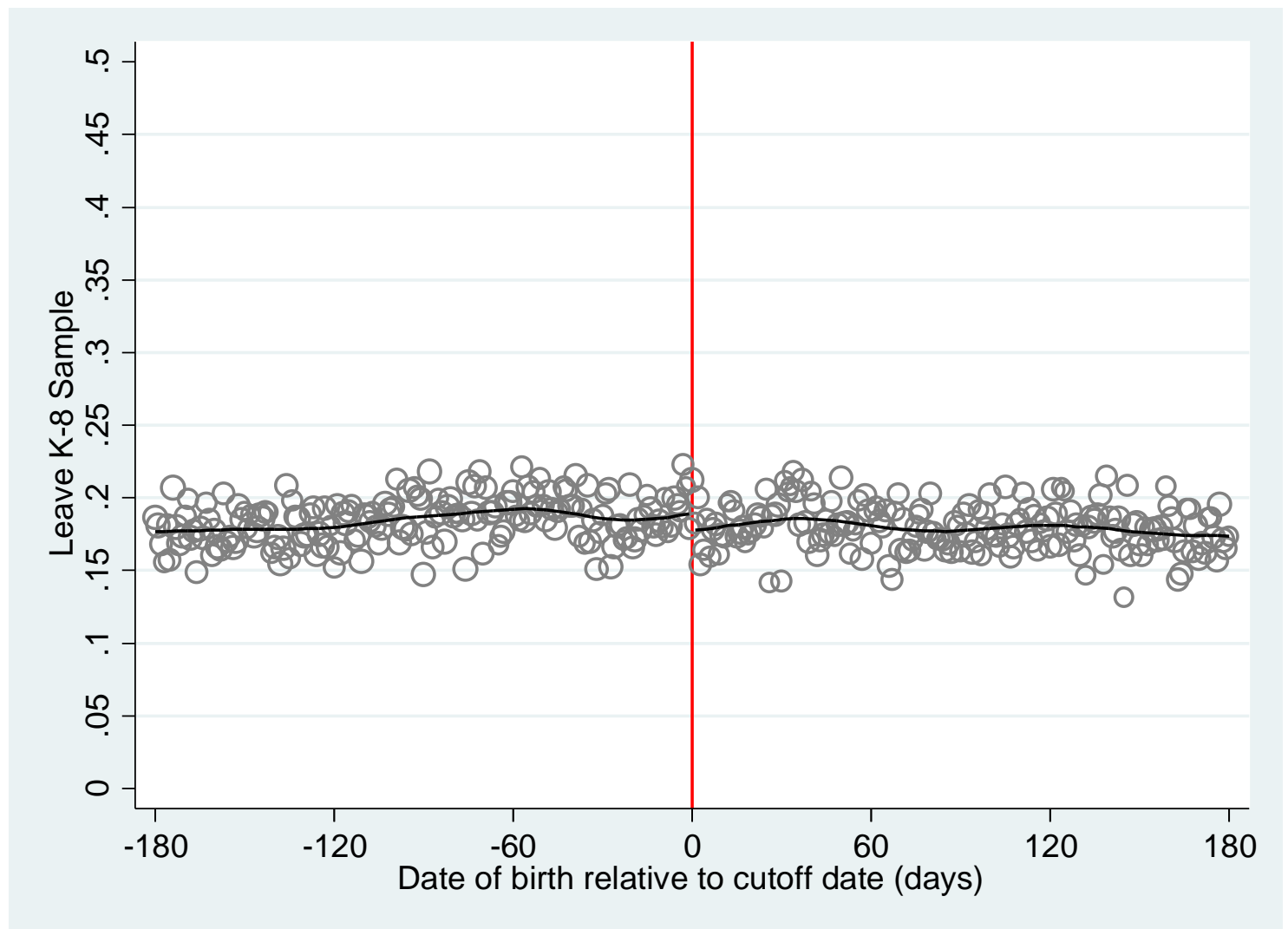

Notes: $\mathrm{N}=227,417$ students; Analytic sample excludes special education students. Means are plotted for each day of birth and depicted as hallow circles; the larger the circle, the greater the number of students born on that day. A weighted local polynomial regression of degree zero fits a line on each side of the cutoff using a triangular kernel and a bandwidth of 30 days, where weights are equal to the number of students in each circle. 
Figure 3. Effects of School Entry Eligibility on Educational Attainment in Late High School

\section{A. Enroll in $\mathbf{1 1}^{\text {th }}$ Grade}

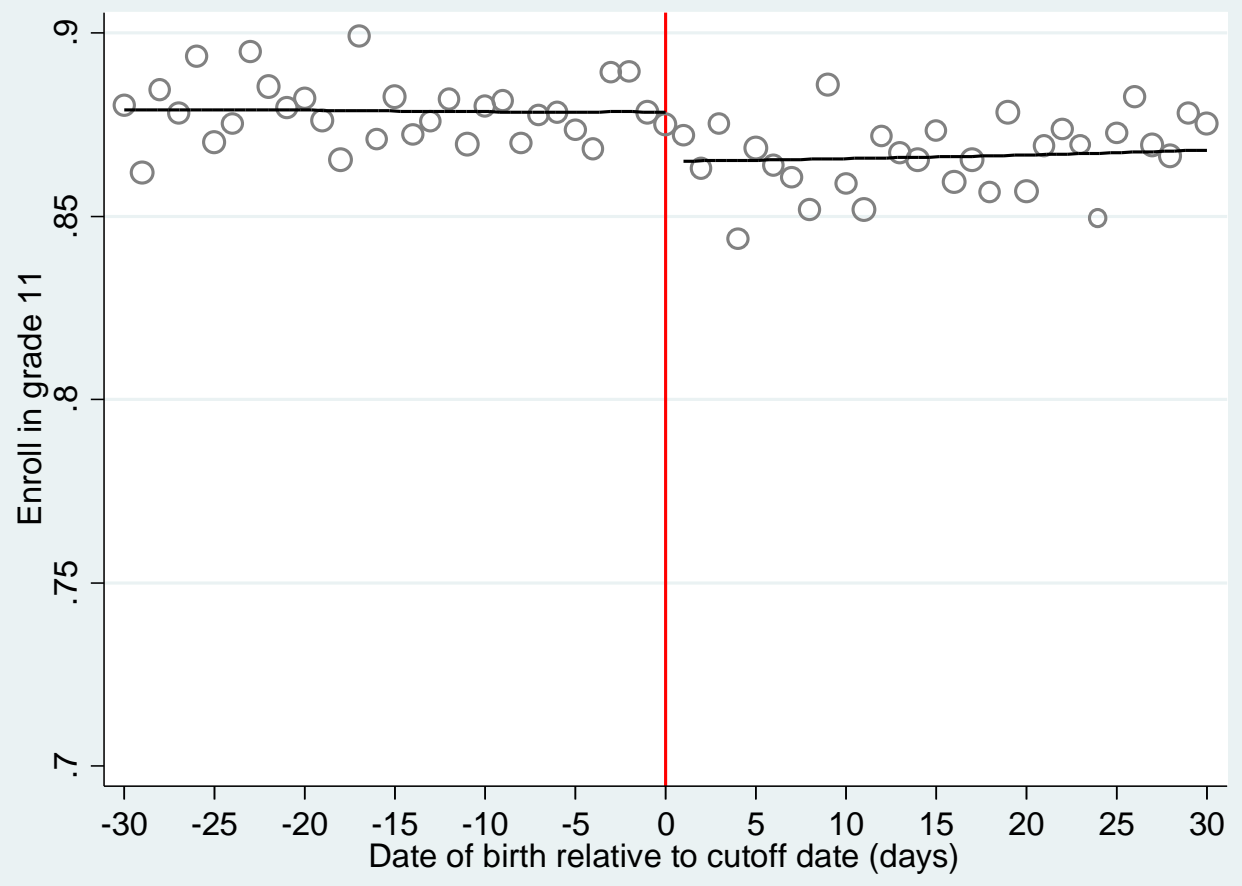

B. Enroll in $12^{\text {th }}$ Grade

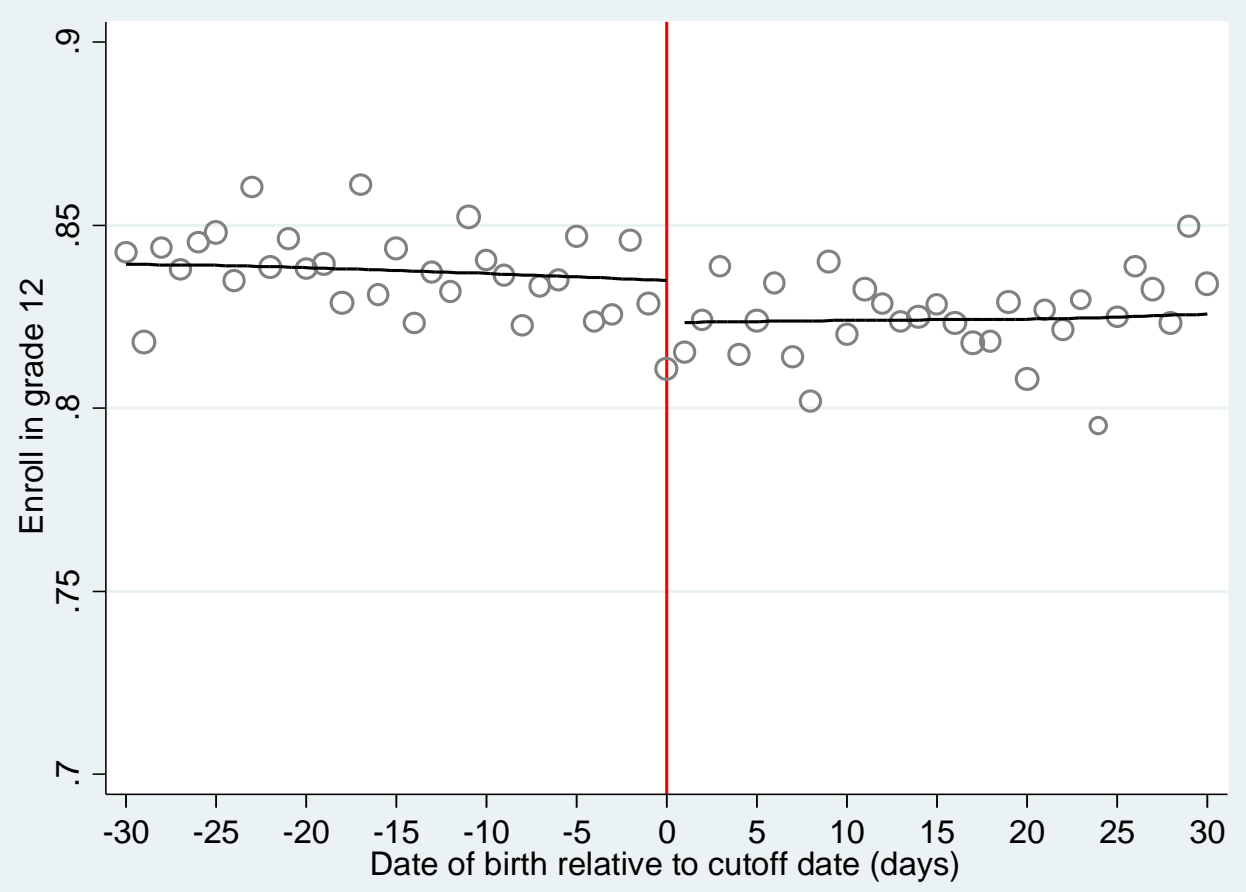




\section{Graduate from High School}

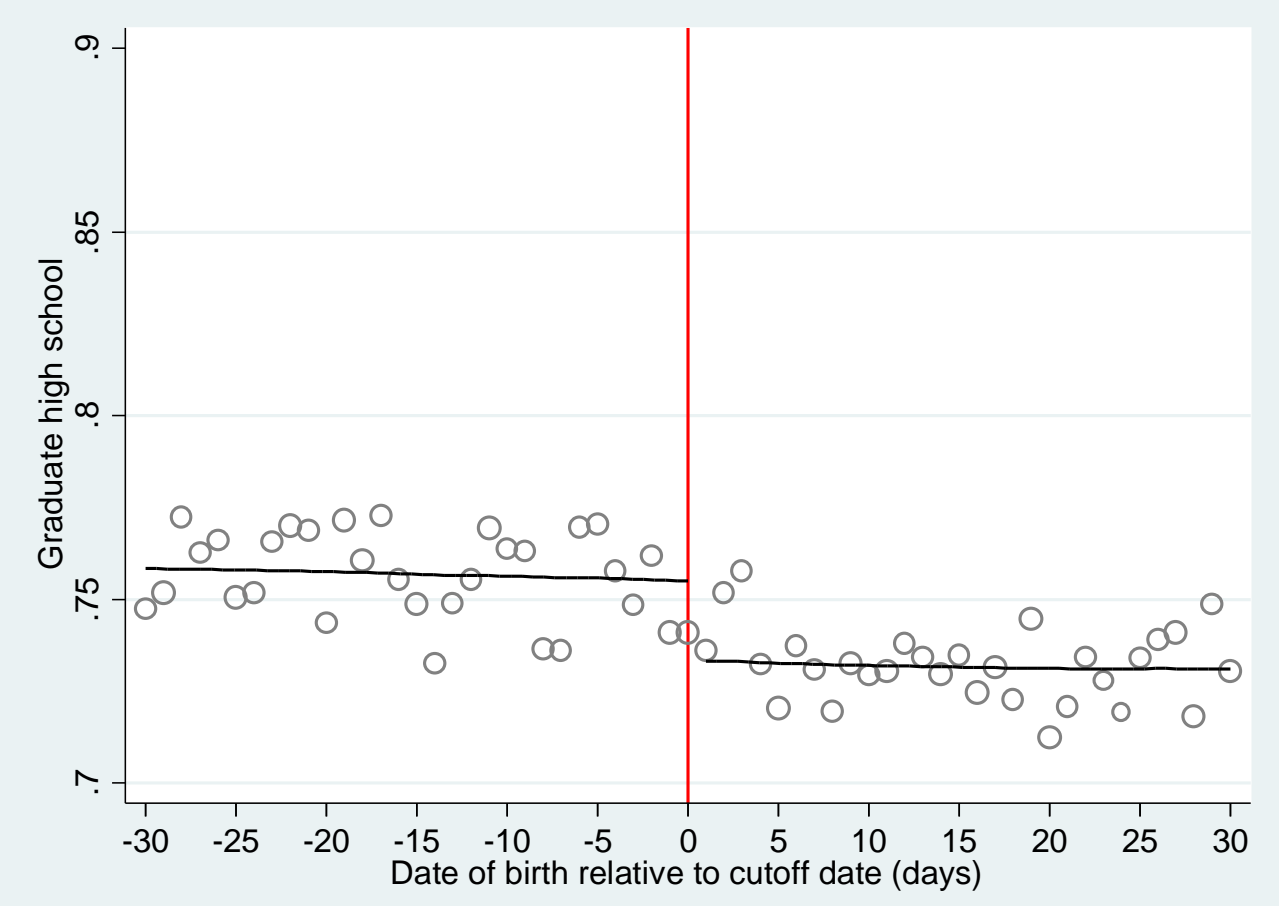

Notes: $\mathrm{N}=88,612$ students; All figures use the high school sample. Means are plotted for each day of birth and depicted as hallow circles; the larger the circle, the greater the number of students born on that day. A weighted local polynomial regression of degree zero fits a line on each side of the cutoff using a triangular kernel and a bandwidth of 30 days, where weights are equal to the number of students in each circle. 
Figure 4. Effects of School Entry Eligibility on College Attendance, Choice, and Persistence

A. Attend College (within 3 years of expected on-time high school graduation)

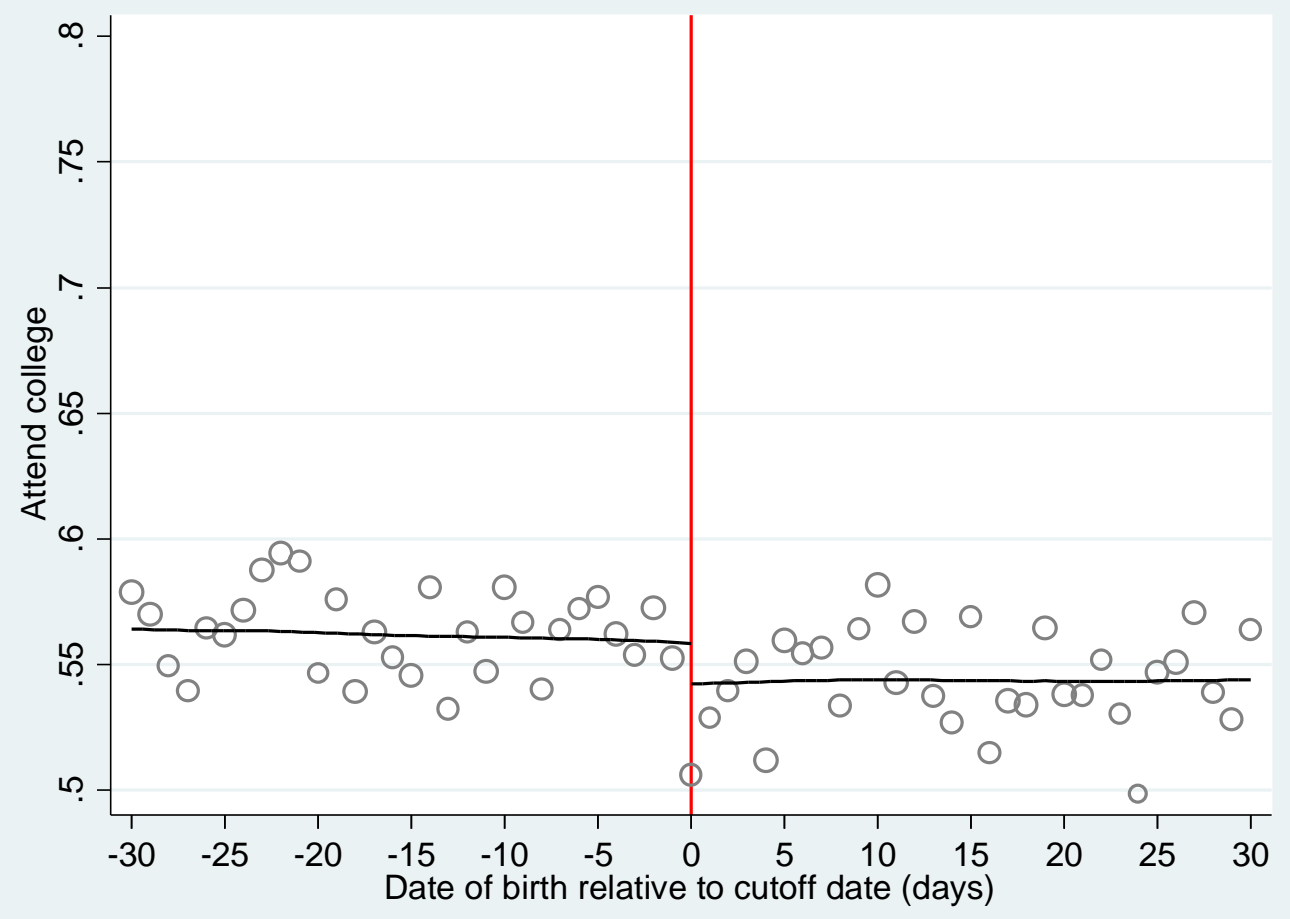

\section{B. First Attend a Two-Year College}

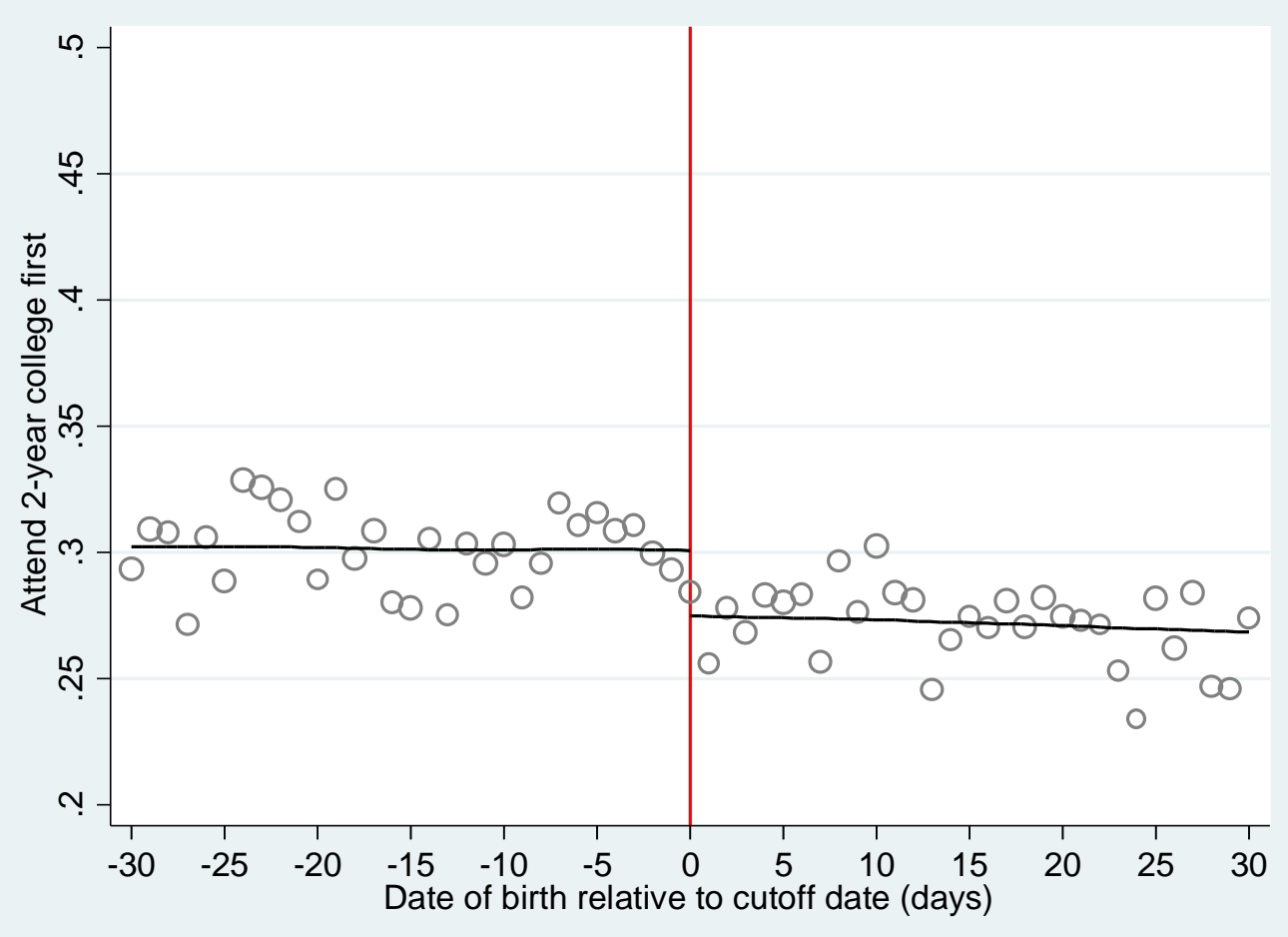




\section{First Attend a Four-Year College}

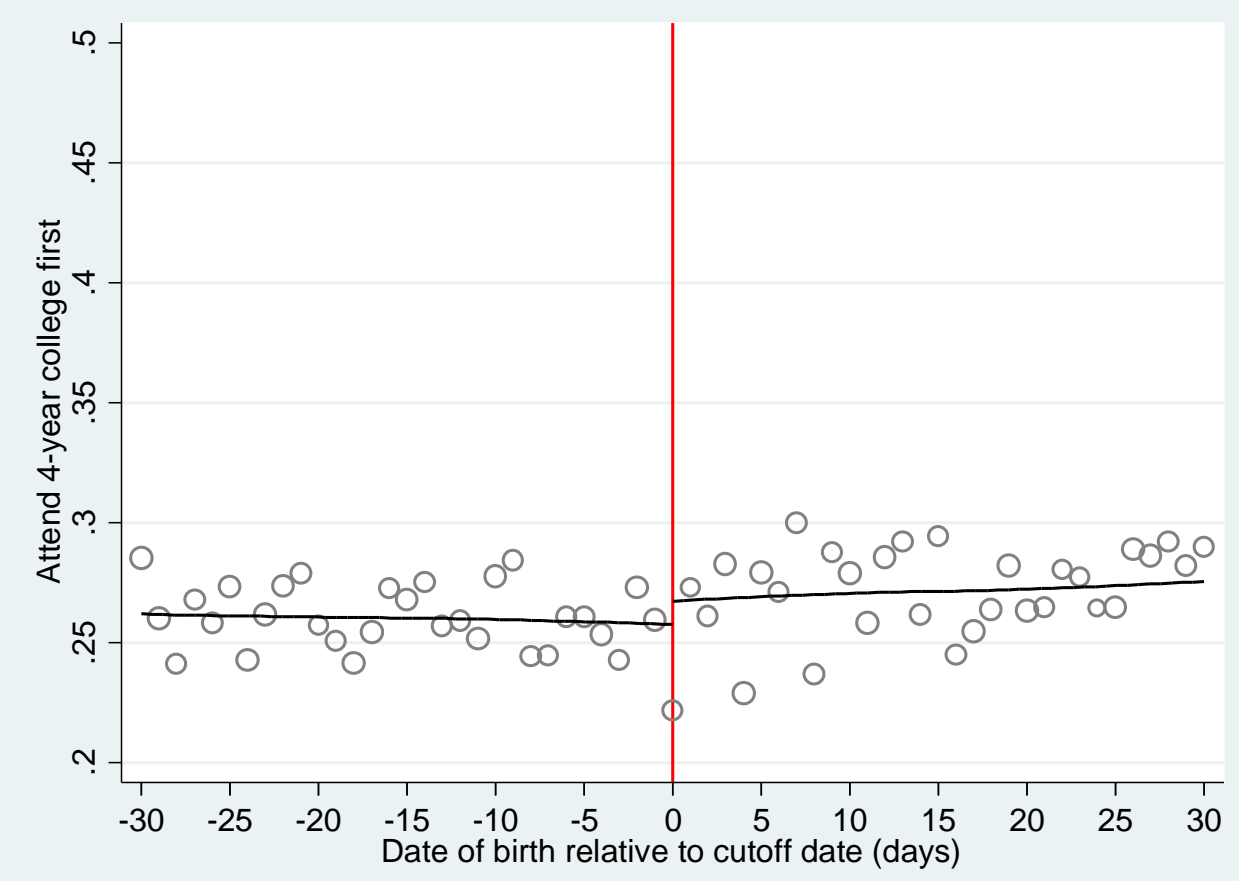

D. Number of Semesters Enrolled in College (within 3 years of expected on-time high school graduation)

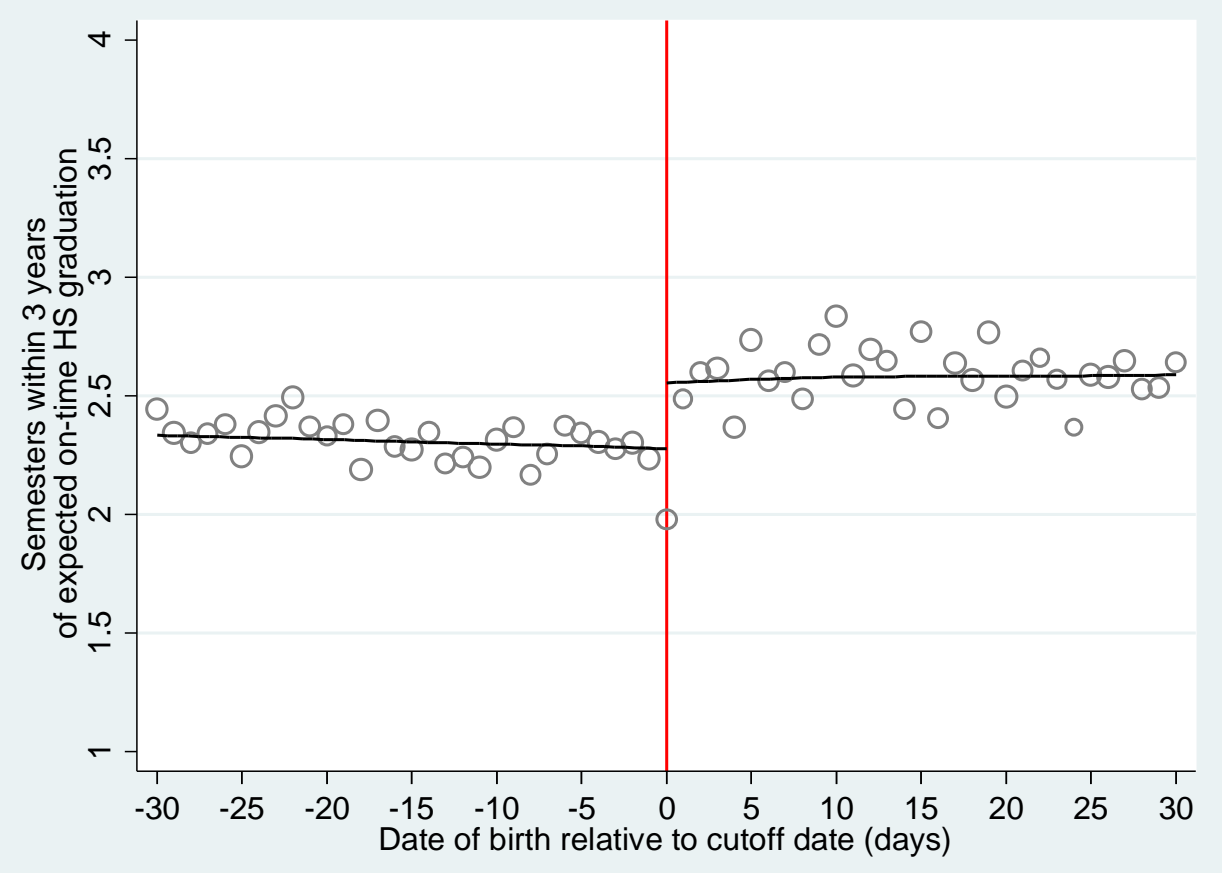

Notes: N = 54,528 students; All figures use the college sample. Means are plotted for each day of birth and depicted as hallow circles; the larger the circle, the greater the number of students born on that day. A weighted local polynomial regression of degree zero fits a line on each side of the cutoff using a triangular kernel and a bandwidth of 30 days, where weights are equal to the number of students in each circle. 


\section{Figure 5. Balance of Covariates at Cutoff: College Sample}

\section{A. Fixed Student Characteristics}
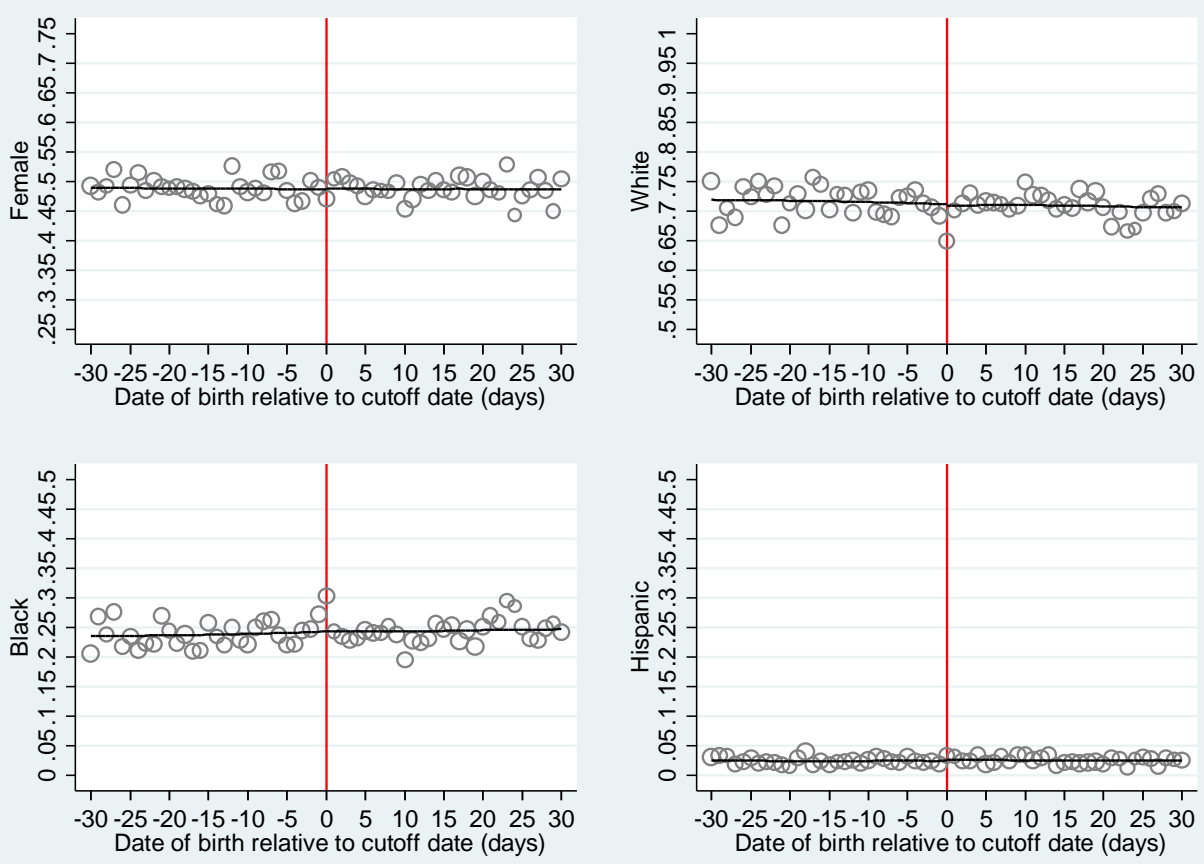

\section{B. Time-Varying Student Characteristics}
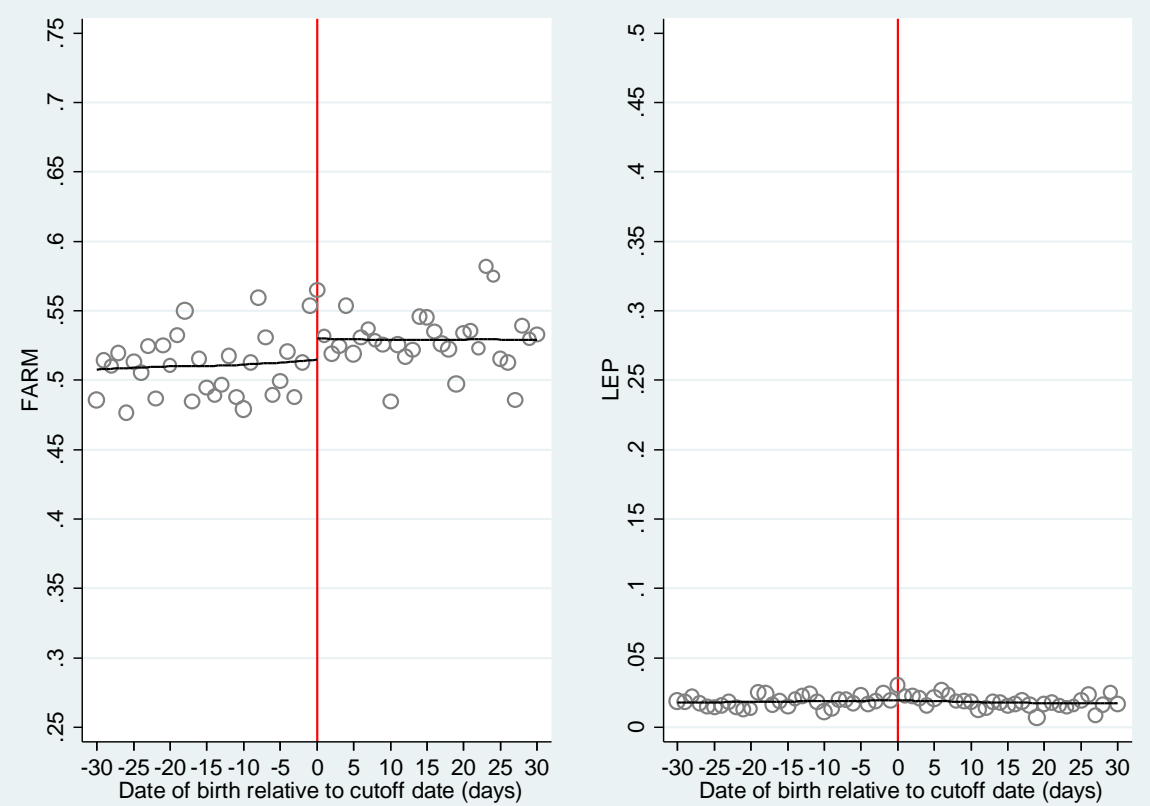

Notes: $N=54,528$ students; All graphs are based on the college sample. Means are plotted for each day of birth and depicted as hallow circles; the larger the circle, the greater the number of students born on that day. A weighted local polynomial regression of degree zero fits a line on each side of the cutoff using a triangular kernel and a bandwidth of 30 days, where weights are equal to the number of students in each circle. The y-axes for the fixed student characteristics measure whether a student was ever identified as the outcome within our data. 
Figure 6. Effect of School Entry Eligibility on Grade Repetition: K-8 Sample

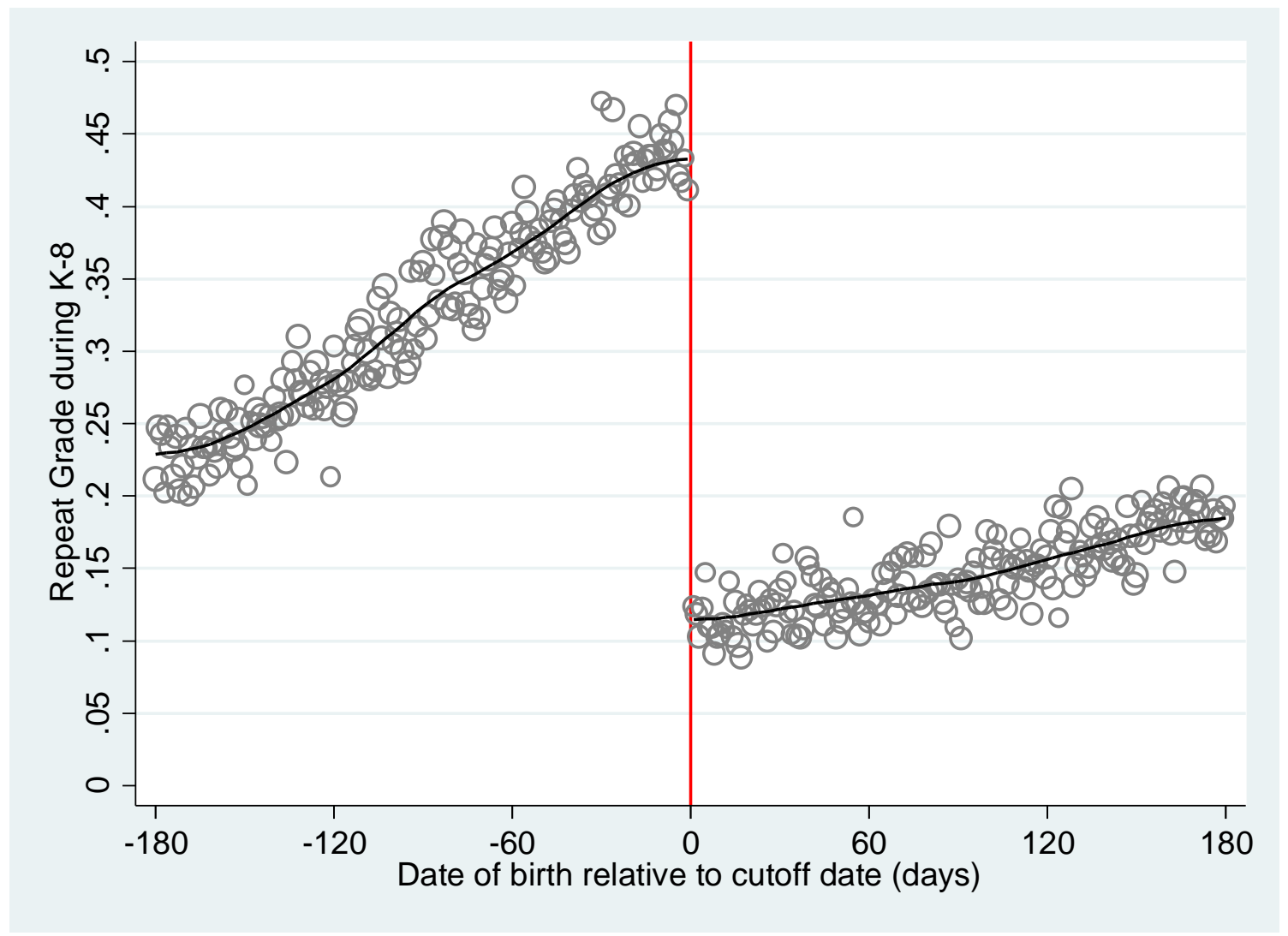

Notes: N = 186,085 students; Analytic (K-8) sample excludes special education students as well as students who leave the data (i.e., Michigan public schools). Means are plotted for each day of birth and depicted as hallow circles; the larger the circle, the greater the number of students born on that day. A weighted local polynomial regression of degree zero fits a line on each side of the cutoff using a triangular kernel and a bandwidth of 30 days, where weights are equal to the number of students in each circle. 
Figure 7. Effect of School Entry Eligibility on Timely Progression through Elementary and Middle School

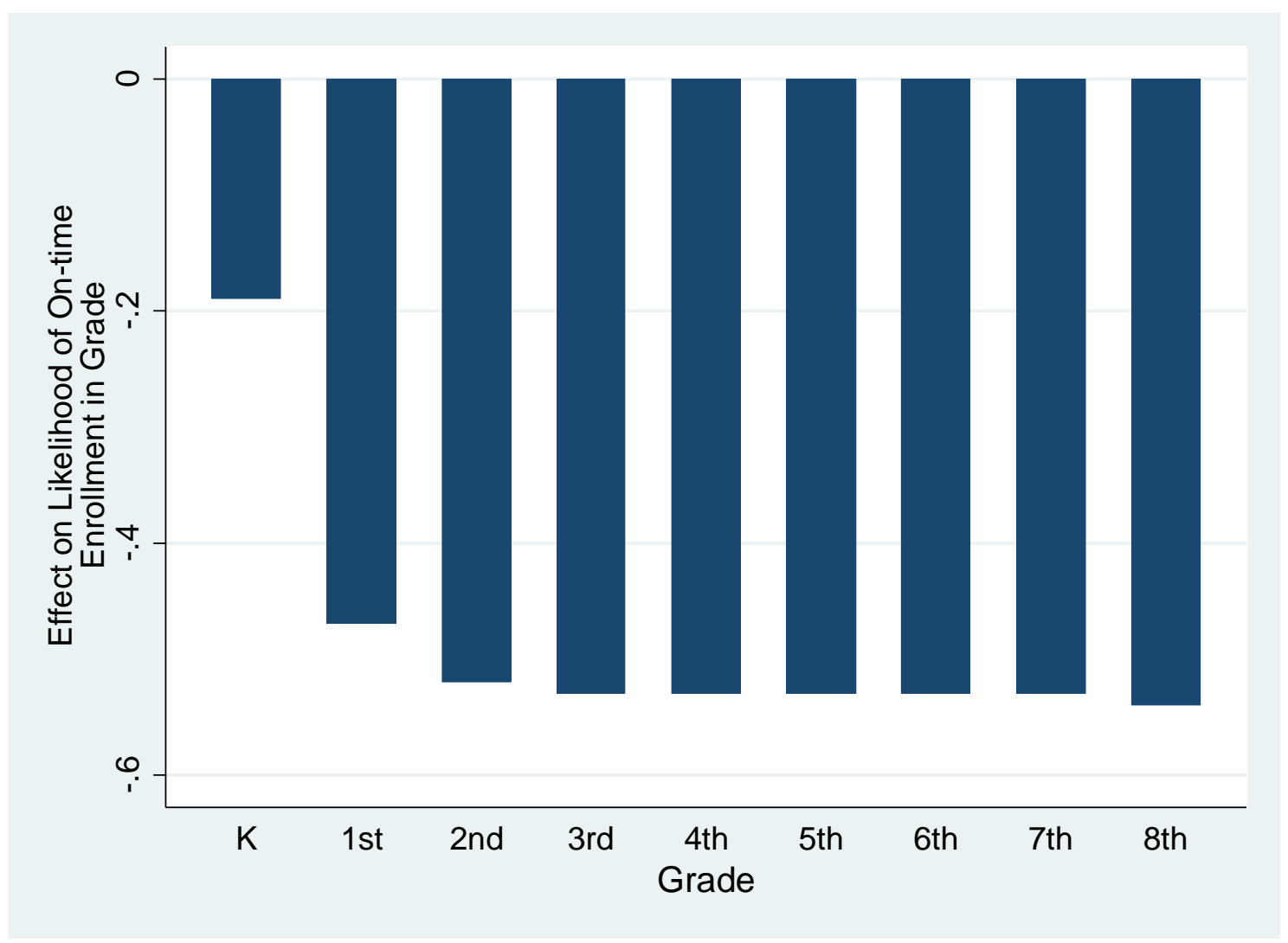

Notes: $\mathrm{N}=$ 29,624 students; Analytic (K-8) sample excludes special education students as well as students who leave the data (i.e., Michigan public schools). Each bar represents a separate effect estimated using a parametric RD model on a window of data that includes 30 days on each side of the cutoff. 
Table 1. Descriptive Statistics by Sample

\begin{tabular}{|c|c|c|c|c|c|c|}
\hline \multicolumn{7}{|c|}{ A. Postsecondary Sample (Born 1989 - 1992) } \\
\hline \multirow{2}{*}{$\begin{array}{l}\text { Data window } \\
\text { Variable } \\
\end{array}$} & \multicolumn{2}{|c|}{ +/- 120 days } & \multicolumn{2}{|c|}{ +/-45 days } & \multicolumn{2}{|c|}{ +/- 30 days } \\
\hline & Mean & $\begin{array}{c}\text { Standard } \\
\text { Deviation }\end{array}$ & Mean & $\begin{array}{c}\text { Standard } \\
\text { Deviation }\end{array}$ & Mean & $\begin{array}{l}\text { Standard } \\
\text { Deviation }\end{array}$ \\
\hline Female & 0.49 & 0.50 & 0.49 & 0.50 & 0.49 & 0.50 \\
\hline White & 0.72 & 0.45 & 0.71 & 0.45 & 0.71 & 0.45 \\
\hline Black & 0.24 & 0.42 & 0.24 & 0.43 & 0.24 & 0.43 \\
\hline Hispanic & 0.02 & 0.16 & 0.02 & 0.16 & 0.02 & 0.15 \\
\hline Other & 0.01 & 0.11 & 0.01 & 0.11 & 0.01 & 0.12 \\
\hline FARM & 0.51 & 0.50 & 0.52 & 0.50 & 0.52 & 0.50 \\
\hline LEP & 0.02 & 0.13 & 0.02 & 0.13 & 0.02 & 0.13 \\
\hline $\mathrm{N}$ & & & & & & \\
\hline \multicolumn{7}{|c|}{ B. High School Sample (Born 1989 - 1994) } \\
\hline Data window & \multicolumn{2}{|c|}{ +/- 120 days } & \multicolumn{2}{|c|}{ +/- 45 days } & \multicolumn{2}{|c|}{ +/- 30 days } \\
\hline Variable & Mean & $\begin{array}{c}\text { Standard } \\
\text { Deviation }\end{array}$ & Mean & $\begin{array}{c}\text { Standard } \\
\text { Deviation }\end{array}$ & Mean & $\begin{array}{c}\text { Standard } \\
\text { Deviation }\end{array}$ \\
\hline Female & 0.49 & 0.50 & 0.49 & 0.50 & 0.49 & 0.50 \\
\hline White & 0.72 & 0.45 & 0.71 & 0.45 & 0.71 & 0.45 \\
\hline Black & 0.23 & 0.42 & 0.24 & 0.43 & 0.24 & 0.43 \\
\hline Hispanic & 0.03 & 0.16 & 0.03 & 0.16 & 0.03 & 0.16 \\
\hline Other & 0.02 & 0.15 & 0.02 & 0.15 & 0.02 & 0.15 \\
\hline FARM & 0.54 & 0.50 & 0.55 & 0.50 & 0.55 & 0.50 \\
\hline LEP & 0.02 & 0.14 & 0.02 & 0.15 & 0.02 & 0.14 \\
\hline $\mathrm{N}$ & & & & & & \\
\hline \multicolumn{7}{|c|}{ C. K-8 Sample (Born 1997 - 1999) } \\
\hline Data window & \multicolumn{2}{|c|}{ +/- 120 days } & \multicolumn{2}{|c|}{ +/- 45 days } & \multicolumn{2}{|c|}{ +/- 30 days } \\
\hline Variable & Mean & $\begin{array}{c}\text { Standard } \\
\text { Deviation }\end{array}$ & Mean & $\begin{array}{c}\text { Standard } \\
\text { Deviation }\end{array}$ & Mean & $\begin{array}{l}\text { Standard } \\
\text { Deviation }\end{array}$ \\
\hline Female & 0.49 & 0.50 & 0.49 & 0.50 & 0.49 & 0.50 \\
\hline White & 0.69 & 0.46 & 0.68 & 0.46 & 0.69 & 0.46 \\
\hline Black & 0.20 & 0.40 & 0.20 & 0.40 & 0.20 & 0.40 \\
\hline Hispanic & 0.06 & 0.24 & 0.06 & 0.24 & 0.06 & 0.24 \\
\hline Other & 0.05 & 0.21 & 0.05 & 0.22 & 0.05 & 0.22 \\
\hline FARM & 0.62 & 0.49 & 0.62 & 0.48 & 0.63 & 0.48 \\
\hline LEP & 0.08 & 0.27 & 0.08 & 0.27 & 0.08 & 0.27 \\
\hline $\mathrm{N}$ & \multicolumn{2}{|c|}{155893} & \multicolumn{2}{|c|}{56848} & \multicolumn{2}{|c|}{38220} \\
\hline
\end{tabular}

Notes: Samples exclude special education students. See text for additional sample-specific construction details. 
Table 2. Effects of School Entry Eligibility on Educational Attainment through High School

\begin{tabular}{|c|c|c|c|c|c|c|c|c|c|c|c|c|}
\hline \multirow[b]{2}{*}{ Independent variable } & \multicolumn{4}{|c|}{ Enroll in 11th grade } & \multicolumn{4}{|c|}{ Enroll in 12th grade } & \multicolumn{4}{|c|}{ Graduate high school } \\
\hline & $(1)$ & $(2)$ & $(3)$ & $(4)$ & $(5)$ & $(6)$ & $(7)$ & $(8)$ & $(9)$ & $(10)$ & $(11)$ & $(12)$ \\
\hline Treat & $\begin{array}{c}0.015^{* * *} \\
(0.004)\end{array}$ & $\begin{array}{c}0.014 * * * \\
(0.004)\end{array}$ & $\begin{array}{c}0.016^{* * *} \\
(0.005)\end{array}$ & $\begin{array}{c}0.016^{* * *} \\
(0.005)\end{array}$ & $\begin{array}{c}0.011^{* * *} \\
(0.004)\end{array}$ & $\begin{array}{c}0.010^{* * *} \\
(0.004)\end{array}$ & $\begin{array}{l}0.010^{*} \\
(0.005)\end{array}$ & $\begin{array}{l}0.010^{* *} \\
(0.005)\end{array}$ & $\begin{array}{c}0.021^{* * *} \\
(0.005)\end{array}$ & $\begin{array}{c}0.019 * * * \\
(0.005)\end{array}$ & $\begin{array}{c}0.016^{* * *} \\
(0.006)\end{array}$ & $\begin{array}{c}0.015^{* * *} \\
(0.006)\end{array}$ \\
\hline Running & $\begin{array}{l}0.000^{*} \\
(0.000)\end{array}$ & $\begin{array}{c}0.000^{* *} \\
(0.000)\end{array}$ & $\begin{array}{c}0.000 \\
(0.000)\end{array}$ & $\begin{array}{c}0.000 \\
(0.000)\end{array}$ & $\begin{array}{c}0.000 \\
(0.000)\end{array}$ & $\begin{array}{c}0.000 \\
(0.000)\end{array}$ & $\begin{array}{c}0.000 \\
(0.000)\end{array}$ & $\begin{array}{c}0.000 \\
(0.000)\end{array}$ & $\begin{array}{c}-0.000 \\
(0.000)\end{array}$ & $\begin{array}{c}0.000 \\
(0.000)\end{array}$ & $\begin{array}{l}-0.000 \\
(0.000)\end{array}$ & $\begin{array}{l}-0.000 \\
(0.000)\end{array}$ \\
\hline Treat*Running & $\begin{array}{c}-0.000 * * \\
(0.000)\end{array}$ & $\begin{array}{c}-0.000^{* *} \\
(0.000)\end{array}$ & $\begin{array}{l}-0.000 \\
(0.000)\end{array}$ & $\begin{array}{l}-0.000 \\
(0.000)\end{array}$ & $\begin{array}{l}-0.000 \\
(0.000)\end{array}$ & $\begin{array}{l}-0.000 \\
(0.000)\end{array}$ & $\begin{array}{c}-0.001^{* *} \\
(0.000)\end{array}$ & $\begin{array}{l}-0.000 \\
(0.000)\end{array}$ & $\begin{array}{l}-0.000 \\
(0.000)\end{array}$ & $\begin{array}{l}-0.000 \\
(0.000)\end{array}$ & $\begin{array}{l}-0.000 \\
(0.000)\end{array}$ & $\begin{array}{c}0.000 \\
(0.000)\end{array}$ \\
\hline Data window & +/- 45 days & +/- 45 days & +/- 30 days & +/- 30 days & +/- 45 days & +/- 45 days & +/- 30 days & +/- 30 days & +/- 45 days & +/- 45 days & +/- 30 days & +/- 30 days \\
\hline Include student-level covariates & No & Yes & No & Yes & No & Yes & No & Yes & No & Yes & No & Yes \\
\hline Outcome mean & 0.87 & 0.87 & 0.87 & 0.87 & 0.83 & 0.83 & 0.83 & 0.83 & 0.74 & 0.74 & 0.74 & 0.74 \\
\hline $\mathrm{N}$ & 131341 & 131341 & 88612 & 88612 & 131341 & 131341 & 88612 & 88612 & 131341 & 131341 & 88612 & 88612 \\
\hline
\end{tabular}

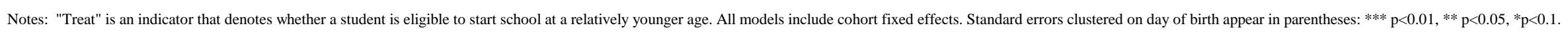


Table 3. Effects of School Entry Eligibility on Academic Achievement in High School

\begin{tabular}{lcccc}
\hline & \multicolumn{4}{c}{ ACT Composite Score } \\
Independent variable & $(1)$ & $(2)$ & $(3)$ & $(4)$ \\
\hline \hline Treat & $-0.356^{* * *}$ & $-0.413^{* * *}$ & $-0.371^{* * *}$ & $-0.433^{* * *}$ \\
& $(0.081)$ & $(0.070)$ & $(0.097)$ & $(0.087)$ \\
Running & -0.003 & -0.002 & 0.001 & -0.001 \\
& $(0.002)$ & $(0.002)$ & $(0.004)$ & $(0.003)$ \\
Treat*Running & 0.002 & 0.002 & -0.006 & -0.002 \\
& $(0.003)$ & $(0.003)$ & $(0.005)$ & $(0.005)$ \\
& & & & \\
Data window & $+/-45$ days & $+/-45$ days & $+/-30$ days & $+/-30$ days \\
Include student-level covariates? & No & Yes & No & Yes \\
Outcome mean & 18.73 & 18.73 & 18.75 & 18.75 \\
$\mathrm{~N}$ & 60887 & 60887 & 41325 & 41325 \\
\hline
\end{tabular}

Notes: "Treat" is an indicator that denotes whether a student is eligible to start school at a relatively younger age. The ACT composite outcome records the score from a student's first attempt. All models include cohort fixed effects. Standard errors clustered on day of birth appear in parentheses: ${ }^{* * *} \mathrm{p}<0.01,{ }^{* *} \mathrm{p}<0.05,{ }^{*} \mathrm{p}<0.1$. 
Table 4. Effects of School Entry Eligibility on College Attendance, Choice, and Persistence

\begin{tabular}{|c|c|c|c|c|c|c|c|c|c|c|c|c|c|c|c|c|}
\hline \multirow[b]{2}{*}{ Independent variable } & \multicolumn{4}{|c|}{$\begin{array}{l}\text { Enroll in college (within } 3 \text { years of expected on-time } \\
\text { high school graduation) }\end{array}$} & \multicolumn{4}{|c|}{ First enrollment is in a 2-year college } & \multicolumn{4}{|c|}{ First enrollment is in a 4-year college } & \multicolumn{4}{|c|}{$\begin{array}{l}\text { Number of semesters enrolled (within } 3 \text { years of } \\
\text { expected on-time high school graduation) }\end{array}$} \\
\hline & (1) & (2) & (3) & (4) & (5) & (6) & (7) & (8) & (9) & $(10)$ & $(11)$ & $(12)$ & (13) & (14) & (15) & (16) \\
\hline Treat & (20.014 & $\begin{array}{l}0.012 \\
\end{array}$ & $\begin{array}{l}0.008 \\
\end{array}$ & (20.007 & 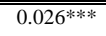 & 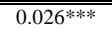 & $\begin{array}{l}0.019 * * \\
\end{array}$ & 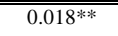 & 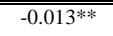 & "-0.014** & $\begin{array}{l}-0.011 \\
\end{array}$ & 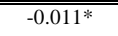 & $\begin{array}{l}-0.343^{* * * *} \\
\end{array}$ & (-0.354*** & 年- $0.375^{* * * *}$ & (-0.378*** \\
\hline & $(0.008)$ & $(0.007)$ & $(0.010)$ & $(0.009)$ & $(0.007)$ & $(0.007)$ & $(0.008)$ & $(0.008)$ & $(0.006)$ & $(0.006)$ & $(0.008)$ & $(0.007)$ & $(0.044)$ & $(0.037)$ & $(0.053)$ & $(0.045)$ \\
\hline Running & $\begin{array}{c}0.000 \\
(0.000)\end{array}$ & $\begin{array}{c}0.000 \\
(0.000)\end{array}$ & $\begin{array}{r}-0.000 \\
(0.000)\end{array}$ & $\begin{array}{c}0.000 \\
(0.000)\end{array}$ & $\begin{array}{l}-0.000 \\
(0.000)\end{array}$ & $\begin{array}{l}-0.000 \\
(0.000)\end{array}$ & $\begin{array}{l}-0.001 \\
(0.000)\end{array}$ & $\begin{array}{l}-0.001 \\
(0.000)\end{array}$ & $\begin{array}{l}0.000^{*} \\
(0.000)\end{array}$ & $\begin{array}{c}0.000^{* *} \\
(0.000)\end{array}$ & $\begin{array}{c}0.001^{*} \\
(0.000)\end{array}$ & $\begin{array}{c}0.001 * * \\
(0.000)\end{array}$ & $\begin{array}{c}0.001 \\
(0.001)\end{array}$ & $\begin{array}{c}0.002 \\
(0.001)\end{array}$ & $\begin{array}{l}-0.000 \\
(0.002)\end{array}$ & $\begin{array}{c}0.000 \\
(0.002)\end{array}$ \\
\hline Treat*Running & $\begin{array}{c}-0.000 \\
(0.000)\end{array}$ & $\begin{array}{c}-0.000 \\
(0.000)\end{array}$ & $\begin{array}{c}-0.001 \\
(0.001)\end{array}$ & $\begin{array}{c}-0.000 \\
(0.000)\end{array}$ & $\begin{array}{c}0.000 \\
(0.000)\end{array}$ & $\begin{array}{c}0.000 \\
(0.000)\end{array}$ & $\begin{array}{c}0.000 \\
(0.000)\end{array}$ & $\begin{array}{c}0.000 \\
(0.000)\end{array}$ & $\begin{array}{c}-0.001 * * \\
(0.000)\end{array}$ & $\begin{array}{c}-0.001 * * * * \\
(0.000)\end{array}$ & $\begin{array}{c}-0.001 * * \\
(0.000)\end{array}$ & $\begin{array}{l}-0.001^{*} \\
(0.000)\end{array}$ & $\begin{array}{c}-0.005^{* * *} \\
(0.002)\end{array}$ & $\begin{array}{c}-0.005^{* * * *} \\
(0.001)\end{array}$ & $\begin{array}{c}-0.005^{*} \\
(0.003)\end{array}$ & $\begin{array}{c}-0.004^{*} \\
(0.002)\end{array}$ \\
\hline Data window & $+/-45$ days & $+/-45$ days & $+/-30$ days & $+/-30$ days & $+/-45$ days & $+/-45$ days & $+/-30$ days & $+/-30$ days & $+/-45$ days & $+/-45$ days & $+/-30$ days & $+/-30$ days & $+/-45$ days & $+/-45$ days & $+/-30$ days & +/- 30 days \\
\hline Include student-level covariates? & No & Yes & No & Yes & No & Yes & No & Yes & No & Yes & No & Yes & No & Yes & No & Yes \\
\hline Outcome mean & 0.55 & 0.55 & 0.55 & 0.55 & 0.29 & 0.29 & 0.29 & 0.29 & 0.27 & 0.27 & 0.27 & 0.27 & 2.46 & 2.46 & 2.45 & 2.45 \\
\hline $\mathrm{N}$ & 80971 & 80971 & 54528 & 54528 & 80971 & 80971 & 54528 & 54528 & 80971 & 80971 & 54528 & 54528 & 80971 & 80971 & 54528 & 54528 \\
\hline
\end{tabular}

Notes: "Treat" is an indicator that denotes whether a student is eligible to start school at a relatively younger age. All models include cohort fixed effects. Standard errors clustered on day of birth appear in parentheses: *** $\mathrm{p}<0.01, * * \mathrm{p}<0.05,{ }^{*} \mathrm{p}<0.1$. 
Table 5. Heterogeneous Effects of School Entry Eligibility on High School Performance and Educational Attainment: by Gender and Poverty Status

\begin{tabular}{|c|c|c|c|c|c|c|c|c|}
\hline \multirow{2}{*}{$\begin{array}{l}\text { Subgroup } \\
\text { Outcome }\end{array}$} & \multicolumn{2}{|c|}{ Female } & \multicolumn{2}{|c|}{ Male } & \multicolumn{2}{|c|}{ FARM } & \multicolumn{2}{|c|}{ Non-FARM } \\
\hline & $(1)$ & $(2)$ & (3) & (4) & (5) & (6) & $(7)$ & $(8)$ \\
\hline \multicolumn{9}{|l|}{ High School Outcomes } \\
\hline Enroll in 11th grade & $\begin{array}{l}0.010 * \\
(0.005)\end{array}$ & $\begin{array}{l}0.011^{*} \\
(0.007)\end{array}$ & $\begin{array}{c}0.018^{* * *} \\
(0.005)\end{array}$ & $\begin{array}{c}0.021^{* * *} \\
(0.006)\end{array}$ & $\begin{array}{c}0.024^{* * *} \\
(0.006)\end{array}$ & $\begin{array}{c}0.029 * * * \\
(0.008)\end{array}$ & $\begin{array}{c}0.003 \\
(0.003)\end{array}$ & $\begin{array}{c}0.001 \\
(0.004)\end{array}$ \\
\hline Enroll in 12th grade & $\begin{array}{c}0.007 \\
(0.006)\end{array}$ & $\begin{array}{c}0.007 \\
(0.007)\end{array}$ & $\begin{array}{l}0.014 * * \\
(0.005)\end{array}$ & $\begin{array}{l}0.014 * * \\
(0.006)\end{array}$ & $\begin{array}{c}0.017 * * * \\
(0.006)\end{array}$ & $\begin{array}{l}0.018 * * \\
(0.008)\end{array}$ & $\begin{array}{c}0.003 \\
(0.004)\end{array}$ & $\begin{array}{c}0.001 \\
(0.005)\end{array}$ \\
\hline Graduate high school & $\begin{array}{c}0.022 * * * \\
(0.007)\end{array}$ & $\begin{array}{l}0.020 * * \\
(0.008)\end{array}$ & $\begin{array}{l}0.016 * * \\
(0.007)\end{array}$ & $\begin{array}{c}0.012 \\
(0.008)\end{array}$ & $\begin{array}{c}0.030 * * * \\
(0.007)\end{array}$ & $\begin{array}{c}0.026 * * * \\
(0.009)\end{array}$ & $\begin{array}{c}0.006 \\
(0.005)\end{array}$ & $\begin{array}{c}0.003 \\
(0.007)\end{array}$ \\
\hline ACT Composite Score & $\begin{array}{c}-0.284^{* * *} \\
(0.108)\end{array}$ & $\begin{array}{c}-0.349 * * * \\
(0.115)\end{array}$ & $\begin{array}{c}-0.423^{* * *} \\
(0.097)\end{array}$ & $\begin{array}{c}-0.514^{* * *} \\
(0.120)\end{array}$ & $\begin{array}{c}-0.487 * * * \\
(0.091)\end{array}$ & $\begin{array}{c}-0.404^{* * *} \\
(0.112)\end{array}$ & $\begin{array}{c}-0.325^{* * *} \\
(0.110)\end{array}$ & $\begin{array}{c}-0.457 * * * \\
(0.128)\end{array}$ \\
\hline \multicolumn{9}{|l|}{ Postsecondary Outcomes } \\
\hline Enroll in college & $\begin{array}{l}0.027 * * \\
(0.011)\end{array}$ & $\begin{array}{l}0.027^{*} \\
(0.014)\end{array}$ & $\begin{array}{l}-0.003 \\
(0.010)\end{array}$ & $\begin{array}{l}-0.012 \\
(0.012)\end{array}$ & $\begin{array}{l}-0.002 \\
(0.010)\end{array}$ & $\begin{array}{l}-0.014 \\
(0.013)\end{array}$ & $\begin{array}{c}0.028^{* * *} \\
(0.009)\end{array}$ & $\begin{array}{c}0.031^{* * * *} \\
(0.011)\end{array}$ \\
\hline Enroll in 2-yr college first & $\begin{array}{c}0.030^{* * *} \\
(0.010)\end{array}$ & $\begin{array}{l}0.024 * \\
(0.013)\end{array}$ & $\begin{array}{c}0.022 * * \\
(0.009)\end{array}$ & $\begin{array}{c}0.013 \\
(0.011)\end{array}$ & $\begin{array}{c}0.011 \\
(0.010)\end{array}$ & $\begin{array}{l}-0.002 \\
(0.013)\end{array}$ & $\begin{array}{c}0.042^{* * *} \\
(0.010)\end{array}$ & $\begin{array}{c}0.041^{* * *} \\
(0.011)\end{array}$ \\
\hline Enroll in 4-yr college first & $\begin{array}{l}-0.004 \\
(0.009)\end{array}$ & $\begin{array}{c}0.003 \\
(0.011)\end{array}$ & $\begin{array}{c}-0.024^{* * *} \\
(0.008)\end{array}$ & $\begin{array}{c}-0.025^{* * *} \\
(0.009)\end{array}$ & $\begin{array}{c}-0.014^{* *} \\
(0.006)\end{array}$ & $\begin{array}{l}-0.012 * \\
(0.007)\end{array}$ & $\begin{array}{l}-0.014 \\
(0.010)\end{array}$ & $\begin{array}{l}-0.011 \\
(0.012)\end{array}$ \\
\hline Number of semesters enrolled & $\begin{array}{c}-0.295^{* * *} \\
(0.060)\end{array}$ & $\begin{array}{c}-0.330^{* * *} \\
(0.075)\end{array}$ & $\begin{array}{c}-0.412^{* * *} \\
(0.048)\end{array}$ & $\begin{array}{c}-0.425^{* * *} \\
(0.057)\end{array}$ & $\begin{array}{c}-0.172 * * * \\
(0.043)\end{array}$ & $\begin{array}{c}-0.202^{* * *} \\
(0.051)\end{array}$ & $\begin{array}{c}-0.546^{* * * *} \\
(0.053)\end{array}$ & $\begin{array}{c}-0.569 * * * \\
(0.062)\end{array}$ \\
\hline Data window & +/- 45 days & +/- 30 days & +/- 45 days & +/- 30 days & +/- 45 days & +/- 30 days & +/- 45 days & +/- 30 days \\
\hline N (high school sample) & 64214 & 43240 & 67127 & 45372 & 71893 & 48389 & 59448 & 40223 \\
\hline $\mathrm{N}$ (college sample) & 39437 & 26585 & 41534 & 27943 & 42125 & 28286 & 38846 & 26242 \\
\hline
\end{tabular}

Notes: All models include cohort fixed effects and student-level covariates. Standard errors clustered on day of birth appear in parentheses: $* * * \mathrm{p}<0.01$, ${ }^{* *} \mathrm{p}<0.05$, ${ }^{*} \mathrm{p}<0.1$. 